\title{
COMBINED REMOVAL OF DIESEL SOOT PARTICULATES AND NOX OVER
}

$\mathrm{CeO}_{2}-\mathrm{ZrO}_{2}$ MIXED OXIDES.

\author{
I. Atribak, A. Bueno-López", and A. García-García. \\ Department of Inorganic Chemistry, University of Alicante, \\ Ap.99 E-03080, Alicante, Spain. \\ (atribak@ua.es, agus@ua.es, a.garcia@ua.es)
}

\begin{abstract}
$\mathrm{CeO}_{2}$ and $\mathrm{Ce}-\mathrm{Zr}$ mixed oxides with different $\mathrm{Ce}: \mathrm{Zr}$ ratio have been prepared, characterised by Raman spectroscopy, XRD, TEM, $\mathrm{N}_{2}$ adsorption at $-196^{\circ} \mathrm{C}$ and $\mathrm{H}_{2}-\mathrm{TPR}$, and tested for soot oxidation under $\mathrm{NO}_{\mathrm{x}} / \mathrm{O}_{2}$. Among the different mixed oxides, $\mathrm{Ce}_{0.76} \mathrm{Zr}_{0.24} \mathrm{O}_{2}$ provided the best results. $\mathrm{Ce}_{0.76} \mathrm{Zr}_{0.24} \mathrm{O}_{2}$ presents a higher activity than pure $\mathrm{CeO}_{2}$ for soot oxidation by $\mathrm{NO}_{x} / \mathrm{O}_{2}$ when both catalysts are calcined at $500^{\circ} \mathrm{C}$ (soot oxidation rates at $500^{\circ} \mathrm{C}$ are 14.9 and $11.4 \mu_{\text {soot }} / \mathrm{s}$, respectively), and the catalytic activity of $\mathrm{CeO}_{2}$ decays significantly with calcination temperature (from 500 to $1000^{\circ} \mathrm{C}$ ) while $\mathrm{Ce}_{0.76} \mathrm{Zr}_{0.24} \mathrm{O}_{2}$ presents enhanced thermal stability at temperatures as high as $1000^{\circ} \mathrm{C}$. In addition, $\mathrm{Ce}_{0.76} \mathrm{Zr}_{0.24} \mathrm{O}_{2}$ catalyses more efficiently than $\mathrm{CeO}_{2}$ the reduction of $\mathrm{NO}_{\mathrm{x}}$ by soot around $500^{\circ} \mathrm{C}$, therefore contributing to the decrease of the $\mathrm{NO}_{\mathrm{x}}$ emission level. The catalytic activity of $\mathrm{CeO}_{2}$ and $\mathrm{Ce}_{0.76} \mathrm{Zr}_{0.24} \mathrm{O}_{2}$ for soot oxidation by $\mathrm{NO}_{\mathrm{x}} / \mathrm{O}_{2}$ depends on the textural properties (BET area; crystallite size), but other properties of the oxides, like redox behaviour and/or enhanced lattice oxygen mobility, also play a significant role.
\end{abstract}

Keywords: catalysed soot oxidation; ceria; Ce-Zr mixed oxide; solid solution; soot; $\mathrm{NO}_{\mathrm{x}}$; Diesel pollution control;

\footnotetext{
* Corresponding author

Tel.: +34965903400 (2226)

Fax: +34 965903454
} 


\section{1.- Introduction.}

Ceria is an important material in the framework of the three-way catalysts (TWCs) which are used in gasoline automobile catalytic converters for the treatment of exhaust gases $[1,2]$. One of the key functions of this material is the ability of cerium to switch between the $\mathrm{Ce}^{4+}$ and $\mathrm{Ce}^{3+}$ oxidation states and to incorporate more or less oxygen into their crystal structure depending on various parameters such as the gaseous atmosphere with which they are in contact, temperature and pressure [3]. Therefore, early on, ceria was given a main role as oxygen storage component in order to extend the three-way window on the lean side of stoichiometry by acting as a sink for gas-phase oxygen during rich-tolean transients in air-to-fuel ratio [1-3]. On the other hand, the oxygen storage component could also promote oxidation of reductants, like $\mathrm{CO}$, during lean-to-rich transients [3]. The TWCs formulation has undergone significant advances during the past 20 years, mainly employing ceria in solid solution with other metal oxides, most notably zirconia $[1,4]$. The advanced TWC formulations are capable of much higher temperature operation than their predecessors and have dramatically improved long-term emissions performance [2, 4].

It has been established that addition of zirconium to ceria to form a mixed oxide solution greatly enhances the reducibility of $\mathrm{Ce}^{4+}$ in the catalyst material, which has generated considerable interest in the Ce-Zr system [5-8]. The energetics of the $\mathrm{Ce}^{4+} / \mathrm{Ce}^{3+}$ reduction step and the corresponding formation of oxygen vacancies are likely to be involved [9]. Indeed, it is clear that fundamental solid state properties such as the precise role of structural defects and dopants, the nature of redox reactions to create electronic species (both within the bulk and at the surfaces), as well as the mechanism of oxygen migration, are crucial to the greater understanding of these important materials. 
The unique features of oxygen storage capacity have made Ce-Zr binary oxides important in numerous catalytic processes, besides TWCs, also CO oxidation [10], light hydrocarbon combustion [11,12] and VOC oxidation [13]. The key steps of these reactions are the supply of oxygen by the readily reducible mixed oxide and its re-oxidation by oxygen. The $\mathrm{Ce}-\mathrm{Zr}$ mixed oxides are better catalysts than bare $\mathrm{CeO}_{2}$ because the partial substitution of $\mathrm{Ce}^{4+}$ (ionic radii $=0.97 \AA$ ) with $\mathrm{Zr}^{4+}$ (ionic radii $=0.84 \AA$ ) leads to the deformation of the lattice, improving its oxygen storage capacity, redox properties and thermal resistance $[5-8,14,15]$.

It has been also recently reported [16] the important role of the active oxygen generated by $\mathrm{CeO}_{2}$ in the catalysed oxidation of soot by $\mathrm{O}_{2}$, which seems to be of interest for the utilization of this oxide as catalyst for the regeneration of soot traps fitted in the exhaust of Diesel engines [17, 18]. It has been also shown that ceria doped with $\operatorname{Zr}$ [19], La $[20,21]$ or $\operatorname{Pr}[21]$ results in more active catalysts for soot oxidation by $\mathrm{O}_{2}$, but scarce information has been reported regarding soot combustion under $\mathrm{NOx} / \mathrm{O}_{2}$ mixtures catalysed by Ce-Zr mixed oxides.

The catalytic behaviour of $\mathrm{CeO}_{2}$ for soot oxidation in $\mathrm{O}_{2}$ is not the same than that in the presence of NOx. In a previous study, the catalytic activity of pure $\mathrm{TiO}_{2}, \mathrm{ZrO}_{2}$, and $\mathrm{CeO}_{2}$ for soot oxidation under $\mathrm{NOx}+\mathrm{O}_{2}$ mixtures was compared [22], concluding that the best activity of $\mathrm{CeO}_{2}$ is related to its capacity to accelerate the $\mathrm{NO}$ conversion to $\mathrm{NO}_{2}\left(\mathrm{TiO}_{2}\right.$ and $\mathrm{ZrO}_{2}$ do not catalyse this reaction), $\mathrm{NO}_{2}$ being much more oxidant than $\mathrm{NO}$ and $\mathrm{O}_{2}$ [23]. Rare earth-doped ceria catalysts (Rare earth $=\mathrm{Sm}, \mathrm{Y}, \mathrm{La}$ or Pr) have been also studied for soot oxidation by $\mathrm{NOx} / \mathrm{O}_{2}$, concluding that $\mathrm{La}$ and $\mathrm{Pr}$ doping enhances ceria activity and stability, while Sm and Y do not provide such benefit [24, 25]. 
It has been reported [22] that $\mathrm{CeO}_{2}$ catalyses the reduction of $\mathrm{NOx}$ by soot, removing both Diesel pollutants - soot and $\mathrm{NO}_{\mathrm{x}}$ - simultaneously. The simultaneous removal of NOx and soot was previously studied by Pisarello et al. [26] with catalysts containing $\mathrm{Co}, \mathrm{K}$ and/or $\mathrm{Ba}$ supported on $\mathrm{MgO}, \mathrm{La}_{2} \mathrm{O}_{3}$ and $\mathrm{CeO}_{2}$, concluding that $\mathrm{CeO}_{2}$ supplies the oxygen necessary for the redox mechanism that takes place during the reaction.

The scope of this paper is to study the catalytic performance of $\mathrm{Ce}-\mathrm{Zr}$ mixed oxides for the removal of soot under simulated Diesel exhaust conditions in a gas flow containing $\mathrm{O}_{2}$ and NOx. Special attention is paid to the simultaneous removal of NOx. The catalytic activity of the Ce-Zr mixed oxides is compared with that of pure $\mathrm{CeO}_{2}$ and the thermal stability of the pure and mixed oxides is studied in detail since the thermal stability is a key requirement for the application of these materials in a real soot trap.

\section{2.- Experimental}

\subsection{Catalyst preparation}

Ce-Zr mixed oxides with different metal ratio were prepared by using a coprecipitation route. The required amounts of $\mathrm{ZrO}\left(\mathrm{NO}_{3}\right)_{2} \cdot 6 \mathrm{H}_{2} \mathrm{O}$ and/or $\mathrm{Ce}\left(\mathrm{NO}_{3}\right)_{3} \cdot 6 \mathrm{H}_{2} \mathrm{O}$ (supplied by Aldrich) were dissolved in water and the hydroxides were precipitated by dropping an ammonia solution to keep the $\mathrm{pH}$ about 9 . The precipitates were dried at $90^{\circ} \mathrm{C}$ in air overnight and calcined in air for 3 hours at different temperatures in the range 500$1000^{\circ} \mathrm{C}$. Pure $\mathrm{CeO}_{2}$ and $\mathrm{ZrO}_{2}$ were also prepared following the same procedure.

$\mathrm{CeO}_{2}$ and $\mathrm{ZrO}_{2}$ pure oxides are denoted by $\mathrm{CeO}_{2}-\mathrm{T}$ and $\mathrm{ZrO}_{2}-\mathrm{T}$, respectively, and the $\mathrm{Ce}-\mathrm{Zr}$ mixed oxides are denoted by $\mathrm{Ce}_{\mathrm{x}} \mathrm{Zr}_{1-\mathrm{x}} \mathrm{O}_{2}-\mathrm{T}$, (formal composition, $0<\mathrm{x}<1$ ) where $\mathrm{x}$ is the molar fraction of $\mathrm{CeO}_{2}$ in the mixed oxides and $\mathrm{T}$ is the calcination temperature. 


\subsection{Catalytic tests}

The catalytic tests were performed in a tubular quartz reactor coupled to specific NDIR-UV gas analysers for $\mathrm{CO}, \mathrm{CO}_{2}, \mathrm{NO}, \mathrm{NO}_{2}$ and $\mathrm{O}_{2}$ monitoring. $20 \mathrm{mg}$ of soot and 80 mg of the selected catalyst were mixed in the so-called loose contact conditions [27] and diluted with $\mathrm{SiC}$ to avoid pressure drop and favour heat transfer. The gas mixture used contained $500 \mathrm{ppm} \mathrm{NOx}, 5 \% \mathrm{O}_{2}$ and balance $\mathrm{N}_{2}$, and the gas flow was fixed at $500 \mathrm{ml} / \mathrm{min}$ $\left(\mathrm{GHSV}=30000 \mathrm{~h}^{-1}\right)$.

Two types of experiments were carried out:

i) Temperature Programmed Reactions: the gas mixture was fed to the reactor, which was at room temperature, and then the temperature was increased from room temperature until $700^{\circ} \mathrm{C}$ at $10^{\circ} \mathrm{C} / \mathrm{min}$.

ii) Isothermal Reactions at $500^{\circ} \mathrm{C}$ : the temperature was raised from room temperature until $500^{\circ} \mathrm{C}$, maintaining the soot-catalyst mixture in $\mathrm{N}_{2}$ flow, and then the $\mathrm{N}_{2}$ flow was replaced by the reaction gas mixture. These experiments were conducted until total conversion of soot.

The model soot used is a carbon black from Degussa (Printex U), with $<0.1 \%$ ash content, $5 \%$ volatile matter, $92.2 \% \mathrm{C}, 0.6 \% \mathrm{H}, 0.2 \% \mathrm{~N}$ and $0.4 \% \mathrm{~S}$.

Soot conversion profiles were determined from $\mathrm{CO}$ and $\mathrm{CO}_{2}$ evolved and the selectivity of the different catalysts towards $\mathrm{CO}$ emission was determined with the equation:

$$
\mathrm{CO} / \mathrm{CO}_{\mathrm{x}}(\%)=100 \cdot \mathrm{CO} /\left(\mathrm{CO}+\mathrm{CO}_{2}\right)
$$

Blank experiments were performed under the described experimental conditions but without soot, that is, only using catalyst. 


\subsection{Characterization techniques}

The textural properties were determined by multi-point $\mathrm{N}_{2}$ adsorption at $-196^{\circ} \mathrm{C}$ using an automatic Autosorb-6B (Quantachrome equipment). Data were treated in accordance with the BET method. The samples were previously degassed for 4 hours at $250^{\circ} \mathrm{C}$ under vacuum.

A JOEL (JEM-2010) microscope was used to obtain TEM images of the catalysts. Few droplets of an ultrasonically dispersed suspension of each catalyst in ethanol were placed in a grid and dried at ambient conditions for TEM characterisation.

Raman spectra of the catalysts were recorded in a Bruker RFS 100/S Fourier Transform Raman Spectrometer with a variable power Nd:YAG laser source (1064 nm). 64 scans at $85 \mathrm{~mW}$ laser power (70 $\mathrm{mW}$ on the sample) were recorded and no heating of the sample was observed under these conditions.

X-ray difractograms of the catalysts were recorded in a Bruker D8 advance diffractometer, using $\mathrm{CuK}_{\alpha}$ radiation. Spectra were registered between 10 and $80^{\circ}(2 \theta)$ with a step of $0.02^{\circ}$ and a time per step of 3 seconds. The average crystal size (D) of the catalysts was determined using the equations of Scherrer and Williamson-Hall:

$$
\mathrm{D}=\frac{\mathrm{K} \cdot \lambda}{\beta \cdot \cos \theta} \quad \text { Scherrer's equation }
$$

where $\lambda$ is the wavelength of the radiation used $\left(\lambda=0.15418 \mathrm{~nm}\right.$ for $\left.\mathrm{CuK}_{\alpha}\right), \beta$ is the full width at half maximum of the diffraction peak considered (111), $\mathrm{K}$ is a shape factor, which is taken as 0.9 ( 1 being a perfect sphere) and $\theta$ is the diffraction angle at which the peak appears. 
The estimation of crystal size of doped oxides presents some problems, because the introduction of foreign cations within the lattice deforms the structure and affects the $\beta$ values. The Williamson-Hall's equation separates the effects of size and strain in the crystals, and is more convenient for the estimation of crystal size of mixed oxides:

$$
\beta_{\text {Total }}=\beta_{\text {Size }}+\beta_{\text {Strain }}=\frac{0.9 \cdot \lambda}{D \cdot \cos \theta}+\frac{4 \cdot(\Delta d) \cdot \sin \theta}{d \cdot \cos \theta} \quad \text { Williamson-Hall's equation }
$$

where $\beta_{\text {Total }}$ is the full width half maximum of the XRD peak and $\Delta d$ is the difference of the $d$ spacing corresponding to a typical peak. A plot of $\beta_{\text {Total }} \cdot \cos \theta$ against $4 \cdot \sin \theta$ yields the average crystal size from the intercept value. In spite of the improvement introduced by the Williamson-Hall's equation with regard to the Scherrer's equation, the crystal sizes estimated for the Ce-Zr mixed oxides prepared in this study must be considered as semiquantitative values, since some of the data obtained are not fully consistent with the BET areas estimated by $\mathrm{N}_{2}$ adsorption.

The redox behaviour of the catalysts was examined by $\mathrm{H}_{2}$-TemperatureProgrammed Reduction $\left(\mathrm{H}_{2}-\mathrm{TPR}\right)$ in a Micromeritics Pulse ChemiSorb 2705 device consisting of a tubular quartz reactor coupled to a TCD detector in order to monitor $\mathrm{H}_{2}$ consumption. The reducing gas used was $5 \% \mathrm{H}_{2}$ in He. The temperature range explored was from room temperature to $900^{\circ} \mathrm{C}$, and the heating rate $10^{\circ} \mathrm{C} / \mathrm{min}$.

\section{Results and discussion.}

\subsection{Temperature programmed reactions: Soot oxidation.}

On Figure 1, the catalytic activity of two series of $\mathrm{Ce}-\mathrm{Zr}$ mixed oxides, calcined at 500 and $1000{ }^{\circ} \mathrm{C}$ respectively, is compared. The temperature required to convert $50 \%$ of soot (T50\%) in each experiment is plotted as a function of the $\mathrm{Zr}$ molar fraction of the 
catalysts used. The $\mathrm{T} 50 \%$ temperature for the uncatalysed reaction was $606{ }^{\circ} \mathrm{C}$ under the experimental conditions used, and most of the samples decreased this temperature. Among the catalysts calcined at $500^{\circ} \mathrm{C}, \mathrm{CeO}_{2}-500$ and $\mathrm{Ce}_{0.76} \mathrm{Zr}_{0.24} \mathrm{O}_{2}-500$ presented the best performance, and increasing the $\mathrm{Zr}$ loading above this molar fraction has a negative effect on the activity due to the lower amount of Ce available. This is consistent with the fact that the couple $\mathrm{Ce}^{3+/ 4+}$ is the responsible of the catalytic activity for soot oxidation of $\mathrm{CeO}_{2-}$ based catalysts. The same activity trend has been reported [19] for $\mathrm{Ce}_{\mathrm{x}} \mathrm{Zr}_{1-\mathrm{x}} \mathrm{O}_{2}$-catalysed soot combustion in air $\left(0 \leq \mathrm{x} \leq 1.0\right.$ composition; catalysts calcined at $500^{\circ} \mathrm{C}$; soot and catalyst in tight contact), where the highest activity was obtained with cerium-rich mixtures (with $\mathrm{x}$ $=1.0$ and $\mathrm{x}=0.75$ ). The arguments provided [19] to explain these results were: i) ceriumrich samples present higher availability of surface $\mathrm{Ce}^{4+}$ sites and, ii) the better ability of these materials (solid solutions) to donate its oxygen for soot oxidation. The highest catalytic activity of $\mathrm{Ce}_{\mathrm{x}} \mathrm{Zr}_{1-\mathrm{x}} \mathrm{O}_{2}$ mixed oxides with $\mathrm{x} \sim 0.75$, in comparison with higher zirconium loading, has been also reported for the selective catalytic reduction of NOx by hydrocarbons [28].

The activity of the catalysts decreased when they were calcined at $1000{ }^{\circ} \mathrm{C}$ (Figure 1), and the degree of thermal deactivation depends on their composition: (i) pure $\mathrm{CeO}_{2}$ and pure $\mathrm{ZrO}_{2}$ became inactive when calcined at $1000^{\circ} \mathrm{C}$, (ii) $\mathrm{Ce}_{0.76} \mathrm{Zr}_{0.24} \mathrm{O}_{2}$ suffered a partial decrease in activity after calcination at $1000^{\circ} \mathrm{C}$, and (iii) the $\mathrm{Ce}-\mathrm{Zr}$ mixtures with $\mathrm{Zr}$ molar fraction higher than 0.24 calcined at $1000^{\circ} \mathrm{C}$ maintained the poor activity of the counterpart catalysts calcined at $500^{\circ} \mathrm{C}$. The thermal stability of $\mathrm{CeO}_{2}$ is a critical point for its application in catalysis, as occurred in TWCs where the low stability of the pure $\mathrm{CeO}_{2}$ used in early formulations obligated to develop advanced $\mathrm{CeO}_{2}$-based materials with enhanced 
thermal resistance [2]. The effect of foreign cation doping on the thermal stability of $\mathrm{CeO}_{2}$ was extensively investigated by Pijolat et al. [29], concluding that, among the different cations investigated $\left(\mathrm{Th}^{4+}, \mathrm{Zr}^{4+}, \mathrm{Si}^{4+}, \mathrm{La}^{3+}, \mathrm{Y}^{3+}, \mathrm{Sc}^{3+}, \mathrm{Al}^{3+}, \mathrm{Ca}^{2+}\right.$, and $\mathrm{Mg}^{2+}$ ), those with ionic radii smaller than that of $\mathrm{Ce}^{4+}$ effectively stabilised the $\mathrm{CeO}_{2}$ against sintering. This observation is consistent with the improved thermal resistance of $\mathrm{Ce}_{0.76} \mathrm{Zr}_{0.24} \mathrm{O}_{2}$ in comparison to pure $\mathrm{CeO}_{2}$.

An additional feature of the soot oxidation catalysts that must be analysed together with the decrease in soot oxidation temperature is the production of $\mathrm{CO}_{2}$ and/or $\mathrm{CO}$ as soot gasification product, $\mathrm{CO}_{2}$ being the desired gas product due to the high toxicity of $\mathrm{CO}$. A general feature of carbon combustion reactions is that the production of $\mathrm{CO}$ increases and the production of $\mathrm{CO}_{2}$ diminishes with temperature. Therefore, on one hand, whether a catalyst decreases the soot combustion temperature, $\mathrm{CO}_{2}$ formation is favoured and, on the other hand, $\mathrm{CeO}_{2}$-based catalysts are effective to catalyse the oxidation of $\mathrm{CO}$ to $\mathrm{CO}_{2}$ [2]. Both properties of the catalysts determine the amount of $\mathrm{CO}$ and $\mathrm{CO}_{2}$ yielded during the catalysed soot oxidation reactions.

On Figure 2, the percentage of $\mathrm{CO}$ evolved during the experiments performed with the series of catalysts calcined at 500 and $1000^{\circ} \mathrm{C}$ is included. The uncatalysed reaction yields $65 \% \mathrm{CO}$, and all the catalysts decreased this value with the only exception of $\mathrm{CeO}_{2-}$ 1000. The best results were obtained with $\mathrm{CeO}_{2}-500$ and with $\mathrm{Ce}-\mathrm{Zr}$ mixtures with $\mathrm{Zr}$ molar fraction equal or lower than 0.46 . The calcination temperature of the Ce-Zr mixtures had a minor effect on CO selectivity.

As a summary of the results included on Figures 1 and 2, it can be concluded that the best formulation obtained among those tested is $\mathrm{Ce}_{0.76} \mathrm{Zr}_{0.24} \mathrm{O}_{2}$. This material has the same activity and selectivity for $\mathrm{CO}_{2}$ formation than pure $\mathrm{CeO}_{2}$ when both catalysts are 
calcined at $500^{\circ} \mathrm{C}$, but shows enhanced thermal stability, maintaining part of its activity for soot oxidation and selectivity for $\mathrm{CO}_{2}$ formation after calcinations at a temperature as high as $1000^{\circ} \mathrm{C}$. This conclusion is in agreement with that reached by Aneggi et al. [19] for $\mathrm{CeO}_{2}$ - and $\mathrm{Ce}_{0.75} \mathrm{Zr}_{0.25} \mathrm{O}_{2}$-catalysed soot combustion in air (with catalysts calcined at 500 and $800^{\circ} \mathrm{C}$ ), who concluded that the main difference between pure ceria and ceriumzirconium solid solution is related to the stability after calcination.

The effect of calcination temperature on the catalytic activity of $\mathrm{CeO}_{2}, \mathrm{ZrO}_{2}$ and $\mathrm{Ce}_{0.76} \mathrm{Zr}_{0.24} \mathrm{O}_{2}$ was studied in more detail within the range of $500-1000^{\circ} \mathrm{C}$, and the results obtained corresponding to activity and selectivity towards $\mathrm{CO}_{2}$ formation are compiled on Figures 3 and 4, respectively. In all the series of catalysts, the catalytic activity for soot oxidation (Figure 3) decreases with calcination temperature. As expected, $\mathrm{ZrO}_{2}$ presents very poor activity, regardless the calcination temperature [22]. The activity of $\mathrm{CeO}_{2}$ and $\mathrm{Ce}_{0.76} \mathrm{Zr}_{0.24} \mathrm{O}_{2}$ is similar when catalysts are calcined at $500^{\circ} \mathrm{C}$ but not at higher calcination temperatures, $\mathrm{Ce}_{0.76} \mathrm{Zr}_{0.24} \mathrm{O}_{2}$ catalysts being, as a general trend, more active than their counterpart $\mathrm{CeO}_{2}$ catalysts. The activity of $\mathrm{CeO}_{2}$ decreases quite monotonically from 500 to $1000^{\circ} \mathrm{C}, \mathrm{CeO}_{2}-1000$ being not active at all. On the contrary, the activity of $\mathrm{Ce}_{0.76} \mathrm{Zr}_{0.24} \mathrm{O}_{2}$ for soot oxidation suffers a certain decrease between 500 and $600{ }^{\circ} \mathrm{C}(\mathrm{T} 50 \%$ increases from 521 to $543^{\circ} \mathrm{C}$, respectively) but is not further modified significantly until $900^{\circ} \mathrm{C}$, indicating very high thermal stability within the range $600-900^{\circ} \mathrm{C}$. The activity of $\mathrm{Ce}_{0.76} \mathrm{Zr}_{0.24} \mathrm{O}_{2}$ only suffered a further decrease between 900 and $1000^{\circ} \mathrm{C}$, but it still maintains part of its activity.

The effect of calcination temperature on the selectivity towards $\mathrm{CO}_{2}$ formation depends significantly on the catalyst formulation (Figure 4). Regardless the calcination temperature, $\mathrm{Ce}_{0.76} \mathrm{Zr}_{0.24} \mathrm{O}_{2}$ yields a low $\mathrm{CO}$ percentage $(13 \pm 6 \%)$ and $\mathrm{ZrO}_{2}$ a high $\mathrm{CO}$ 
percentage $(53 \pm 12 \%)$. $\mathrm{CO}$ formation during $\mathrm{CeO}_{2}$-catalysed soot oxidation suffers a little increase with catalysts calcined between 500 and $600^{\circ} \mathrm{C}$ but raises drastically between 600 and $800^{\circ} \mathrm{C}$, almost reaching at this temperature the $\mathrm{CO}$ percentage yielded during the uncatalysed reaction. These results confirm that, among the different formulations studied, $\mathrm{Ce}_{0.76} \mathrm{Zr}_{0.24} \mathrm{O}_{2}$ is the best one considering its activity for soot oxidation, high thermal stability and high selectivity towards $\mathrm{CO}_{2}$ formation as soot oxidation product.

\subsection{Temperature programmed reactions: $\mathrm{NO}_{\mathrm{x}}$ elimination.}

The elimination of NOx during the Temperature Programmed Reactions also depended on the catalyst used, as observed on Figure 5a for catalysts calcined at $500^{\circ} \mathrm{C}$. This type of profiles was previously studied in detail for pure $\mathrm{CeO}_{2}$ catalysts [22]. Considering, as an example, the NOx elimination profile obtained with $\mathrm{Ce}_{0.76} \mathrm{Zr}_{0.24} \mathrm{O}_{2}$ (see Figure 5a), three different processes can be distinguished between 225 and $700^{\circ} \mathrm{C}$, that is, the maximum NOx elimination level is reached at $400^{\circ} \mathrm{C}$, and two shoulders appear at higher temperatures, around 500 and $600{ }^{\circ} \mathrm{C}$, respectively. This profile suggests that three different NOx elimination pathways are taking place. The shape of the NOx elimination curves depends on the catalyst used, in other words, the relative importance of each NOx elimination pathway is different for each catalyst. The $\mathrm{NO}_{\mathrm{x}}$ elimination profiles are explained as follows:

- NOx elimination around $400^{\circ} \mathrm{C}$ and lower temperatures: the elimination of $\mathrm{NOx}$ is mainly attributed to NOx chemisorption on the catalysts, as supported by the blank experiments (without soot) included on Figure 6a. NOx chemisorption on $\mathrm{Ce}-\mathrm{Zr}$ mixtures (Figure 5a) around $400^{\circ} \mathrm{C}$ decreases by increasing the $\mathrm{Zr}$ molar fraction, since 
NOx chemisorption occurs on Ce but not on $\mathrm{Zr}$ [22]. The NOx elimination levels reached at $400^{\circ} \mathrm{C}$ by $\mathrm{Ce}_{0.76} \mathrm{Zr}_{0.24} \mathrm{O}_{2}-500$ and $\mathrm{CeO}_{2}-500$ (Figure 5a) are slightly different, while the NOx chemisorption in both catalysts observed in blank experiments (Figure 6a) is the same. This suggests a certain contribution of another NOx elimination pathway (NOx reduction by soot), in addition to NOx chemisorption.

- NOx elimination around $500^{\circ} \mathrm{C}$ : the elimination of NOx around this temperature is partially attributed to the catalysed soot-NOx reaction, and NOx is consumed due to reduction by soot. This is the most interesting NOx elimination pathway, since allows the simultaneous abatement of NOx and soot by reaction of both pollutants to each other. The formation of $\mathrm{N}_{2} \mathrm{O}$, as reaction product, was not detected in additional experiments followed by gas chromatography [22]. $\mathrm{O}_{2}$ is also converted around $500^{\circ} \mathrm{C}$ due to soot combustion, as observed on Figure $5 \mathrm{~b}$. As mentioned in the previous section, the catalytic activity for soot oxidation of the series of catalysts calcined at $500^{\circ} \mathrm{C}$ decreases when the $\mathrm{Zr}$ molar fraction increases (Figure 1), $\mathrm{Ce}_{0.76} \mathrm{Zr}_{0.24} \mathrm{O}_{2}-500$ being the most active Ce-Zr mixture.

- $\mathrm{NO}_{\mathrm{x}}$ elimination around $600^{\circ} \mathrm{C}$ : The elimination of $\mathrm{NO}_{\mathrm{x}}$ around this temperature is mainly attributed to the uncatalysed soot- $\mathrm{NO}_{\mathrm{x}}$ reaction, occurring along with the reaction soot- $\mathrm{O}_{2}$ (see Figure $5 \mathrm{~b}$ ). As observed on Figure 5a, this is the only NOx elimination pathway for the least active catalysts $\left(\mathrm{ZrO}_{2}-500, \mathrm{Ce}_{0.16} \mathrm{Zr}_{0.84} \mathrm{O}_{2}-500\right.$, and $\left.\mathrm{Ce}_{0.34} \mathrm{Zr}_{0.66} \mathrm{O}_{2}-500\right)$.

A key factor influencing the catalysed soot oxidation reactions in the presence of $\mathrm{NOx}$ is the $\mathrm{NO}_{2}$ production by the different catalysts. On Figure $6 \mathrm{~b}$, the $\mathrm{NO}_{2}$ percentage (on the basis of $\mathrm{NO}+\mathrm{NO}_{2}$ ) is plotted as a function of temperature for blank experiments. Above $275^{\circ} \mathrm{C}, \mathrm{Ce}_{0.76} \mathrm{Zr}_{0.24} \mathrm{O}_{2}-500$ and $\mathrm{CeO}_{2}-500$ catalyse the oxidation of $\mathrm{NO}$ to $\mathrm{NO}_{2}$, reaching a 
maximum $\mathrm{NO}_{2}$ level corresponding to the thermodynamic equilibrium at $450^{\circ} \mathrm{C}$, and decreasing at higher temperature following thermodynamics. On the contrary, the catalysts calcined at $1000^{\circ} \mathrm{C}$ are not effective to convert $\mathrm{NO}$ into $\mathrm{NO}_{2}$, which is consistent with the lower activity of the samples $\mathrm{Ce}_{0.76} \mathrm{Zr}_{0.24} \mathrm{O}_{2}-1000$ and $\mathrm{CeO}_{2}-1000$ for soot oxidation in comparison to the counterpart samples calcined at $500^{\circ} \mathrm{C}$. It is well established [30] that the catalytic activity for soot oxidation of ceria-based catalysts under NOx mixtures is related to their ability to accelerate $\mathrm{NO}_{2}$ production, $\mathrm{NO}_{2}$ being more oxidant than $\mathrm{NO}$ and $\mathrm{O}_{2}$.

The effect of calcination temperature of $\mathrm{CeO}_{2}$ and $\mathrm{Ce}_{0.76} \mathrm{Zr}_{0.24} \mathrm{O}_{2}$ on their $\mathrm{NOx}$ elimination capacity was also studied, and the curves obtained during the corresponding Temperature Programmed Reactions are included on Figures 7a and 7b, respectively. As shown on Figure $7 \mathrm{a}$, the amount of NOx removed below $500^{\circ} \mathrm{C}$ is seen decreased with calcination temperature, existing a dramatic decrease from $\mathrm{CeO}_{2}-600$ to $\mathrm{CeO}_{2}-700$. The removal of $\mathrm{NO}_{\mathrm{x}}$ through the uncatalysed reaction (around $600^{\circ} \mathrm{C}$ ) is the main $\mathrm{NOx}$ elimination pathway for $\mathrm{CeO}_{2}$ calcined at $800^{\circ} \mathrm{C}$ and higher temperatures.

The behaviour of $\mathrm{Ce}_{0.76} \mathrm{Zr}_{0.24} \mathrm{O}_{2}$-series (Figure $7 \mathrm{~b}$ ) is different to that of $\mathrm{CeO}_{2}$-series (Figure 7a). $\mathrm{Ce}_{0.76} \mathrm{Zr}_{0.24} \mathrm{O}_{2}$ suffers a gradual decrease in their NOx removal capacity and only the sample $\mathrm{Ce}_{0.76} \mathrm{Zr}_{0.24} \mathrm{O}_{2}-1000$ exhibits a NOx profile ascribed only to the uncatalysed NOx-soot reaction. Once more, NOx elimination profiles allow concluding that $\mathrm{Ce}_{0.76} \mathrm{Zr}_{0.24} \mathrm{O}_{2}$ is the best formulation among those studied, since it presents the best performance among the different catalysts tested and shows enhanced thermal stability with regard to bare $\mathrm{CeO}_{2}$. 


\subsection{Isothermal reactions at $500^{\circ} \mathrm{C}$.}

As described in the previous sections, the results of the temperature programmed reactions indicated that some of the catalysts tested are able to promote the soot-NOx reaction around $500^{\circ} \mathrm{C}$, therefore allowing the simultaneous removal of both NOx and soot. Considering the best performance of $\mathrm{Ce}_{0.76} \mathrm{Zr}_{0.24} \mathrm{O}_{2}$, its catalytic activity has been tested under isothermal conditions at $500^{\circ} \mathrm{C}$, and it has been compared with that of bare $\mathrm{CeO}_{2}$. In both cases, catalysts calcined at 500 and $1000^{\circ} \mathrm{C}$ have been tested. The soot oxidation rates, expressed per gram of soot remaining in the reactor, are included on Figure 8a and the corresponding NOx elimination profiles on Figure 8b. Additionally, the average soot oxidation rates estimated from isothermal experiments at $500^{\circ} \mathrm{C}$ are compiled on Table 1 as well as the percentage of $\mathrm{CO}$ evolved during the experiments and the time required for $75 \%$ soot conversion into $\mathrm{CO}+\mathrm{CO}_{2}$. It is worth mentioning that the uncatalysed soot oxidation at $500^{\circ} \mathrm{C}$ did not take place under these experimental conditions.

$\mathrm{Ce}_{0.76} \mathrm{Zr}_{0.24} \mathrm{O}_{2}-500$ is the most active catalyst for soot oxidation (Figure 8a) and $\mathrm{NO}_{\mathrm{x}}$

reduction (Figure $8 b$ ). The soot oxidation rate during the $\mathrm{Ce}_{0.76} \mathrm{Zr}_{0.24} \mathrm{O}_{2}-500$-catalysed experiment rose with soot conversion until about $25 \%$ of conversion approximately, which can be explained by an increase of the number of actives sites for oxygen chemisorption on the soot surface as a consequence of its progressive oxidation [31, 32]. After a certain conversion, the steady state is reached and a constant rate is maintained. As shown on Table 1, the main reaction product is $\mathrm{CO}_{2}$, mainly for catalysts calcined at $500^{\circ} \mathrm{C}$, with a very low $\mathrm{CO}$ emission (according to TPR results). The reduction of NOx (Figure 8b) decreased progressively with the soot conversion, as expected since less reductant is available, and $\mathrm{NO}_{\mathrm{x}}$ elimination was null after about $75 \%$ soot conversion. However, a low amount of NOx was further eliminated once soot is about consumed, and the $\mathrm{NO}_{\mathrm{x}}$ 
elimination profiles slightly rose at the end of the experiment. This phenomenon was attributed to the chemisorption of NOx on the catalyst [22]. If soot is available (in Figure 8, below $75 \%$ soot conversion for $\mathrm{Ce}_{0.76} \mathrm{Zr}_{0.24} \mathrm{O}_{2}-500$ ) the reaction of $\mathrm{NOx}$ (mainly $\mathrm{NO}_{2}$ ) with soot is preferable to the storage of $\mathrm{NO}_{\mathrm{x}}$ on the catalyst, but once soot is not available (above $75 \%$ soot conversion), NOx chemisorption on the catalyst takes place being the only possible $\mathrm{NO}_{\mathrm{x}}$ elimination pathway.

The calcination temperature of the catalyst diminishes their activity and the soot oxidation rate (Figure 8a) in steady state conditions is about 3 times lower with the catalyst $\mathrm{Ce}_{0.76} \mathrm{Zr}_{0.24} \mathrm{O}_{2}-1000$ than with $\mathrm{Ce}_{0.76} \mathrm{Zr}_{0.24} \mathrm{O}_{2}-500$. Under our experimental conditions, 75\% of the soot used in the experiments was burnt off after 19 and 62 minutes with $\mathrm{Ce}_{0.76} \mathrm{Zr}_{0.24} \mathrm{O}_{2}-500$ and $\mathrm{Ce}_{0.76} \mathrm{Zr}_{0.24} \mathrm{O}_{2}-1000$, respectively. The practical implication of this result is that the regeneration of a DPF loaded with $\mathrm{Ce}_{0.76} \mathrm{Zr}_{0.24} \mathrm{O}_{2}-1000$ would take about 3 times longer that the regeneration of the same filter loaded with $\mathrm{Ce}_{0.76} \mathrm{Zr}_{0.24} \mathrm{O}_{2}-500$. The activity of $\mathrm{CeO}_{2}-500$ also decreased after calcinations at $1000^{\circ} \mathrm{C}$, but in this case the effect of the calcinations temperature was drastic. 172 minutes were required by $\mathrm{CeO}_{2}-1000$ to convert $75 \%$ of the soot used in the experiment while 24 minutes were required by $\mathrm{CeO}_{2^{-}}$ 500. Since in a real filter thermal aging of the catalyst can occur, thermally stable active phases are required and $\mathrm{Ce}_{0.76} \mathrm{Zr}_{0.24} \mathrm{O}_{2}$ is preferable to pure $\mathrm{CeO}_{2}$. In addition, the activity of $\mathrm{CeO}_{2}-500$ for soot oxidation and $\mathrm{NOx}$ reduction under isothermal conditions at $500^{\circ} \mathrm{C}$ is lower than that of $\mathrm{Ce}_{0.76} \mathrm{Zr}_{0.24} \mathrm{O}_{2}-500$ (Figure 8). These differences were not detected in the transient conditions of the Temperature Programmed Reactions (Figures 1 and 3), evidencing the importance of performing experiments under isothermal conditions, which also provide a more realistic picture of the catalytic behaviour under real conditions. 


\subsection{Study of the catalytic activity decay due to thermal aging.}

The thermal deactivation of $\mathrm{CeO}_{2}$ and $\mathrm{Ce}_{0.76} \mathrm{Zr}_{0.24} \mathrm{O}_{2}$ has been studied, and their BET surface areas are represented as a function of the calcination temperature on Figure 9.

The BET surface areas of the samples calcined at $500^{\circ} \mathrm{C}$ are about the same value

$\left(\sim 65 \mathrm{~m}^{2} / \mathrm{g}\right)$, and the surface areas of all the oxides decrease significantly with calcination temperature. $\mathrm{Ce}_{0.76} \mathrm{Zr}_{0.24} \mathrm{O}_{2}$ presents much better thermal resistance than pure $\mathrm{CeO}_{2}$ due to the stabilizing role of $\mathrm{Zr}$. In this type of mixed oxides, the BET value is related to the external surface area of the particles, and high surface area means small particle size and vice versa. The TEM pictures included on Figure 10 are in agreement with this argument and also the crystal sizes determined from XRD by Scherrer and Williamson Hall's equations (Table 2). $\mathrm{CeO}_{2}-500$ and $\mathrm{Ce}_{0.76} \mathrm{Zr}_{0.24} \mathrm{O}_{2}-500$ (Figures $10 \mathrm{a}$ and $10 \mathrm{c}$, respectively) appear in TEM pictures as a quite homogeneous agglomeration of small particles with a particle size around $10-20 \mathrm{~nm}$ in both cases, which is consistent with the crystal sizes determined from the Williamson Hall's equations (22 and $21 \mathrm{~nm}$, respectively). After calcination at $1000^{\circ} \mathrm{C}, \mathrm{CeO}_{2}$ particles grow due to thermal sintering forming particles larger than $100 \mathrm{~nm}$ (Figure $10 \mathrm{~b}$ ) while $\mathrm{Ce}_{0.76} \mathrm{Zr}_{0.24} \mathrm{O}_{2}-1000$ maintains smaller sizes of around 20$30 \mathrm{~nm}$ (Figure $10 \mathrm{~d}$ ). On this line, the Williamson Hall's equation (Table 2) estimates crystal sizes of 107 and $65 \mathrm{~nm}$ for $\mathrm{CeO}_{2}-1000$ and $\mathrm{Ce}_{0.76} \mathrm{Zr}_{0.24} \mathrm{O}_{2}-1000$, respectively.

The structural characterization of $\mathrm{CeO}_{2}$ and $\mathrm{Ce}_{0.76} \mathrm{Zr}_{0.24} \mathrm{O}_{2}$ samples was carried out by XRD and Raman spectroscopy (Figures 11 and 12 respectively). All the diffractograms included on Figures $11 \mathrm{a}$ and $11 \mathrm{~b}$ contain the main reflections typical of a fluorite-structured material with a fec unit cell at $28.5,33.1,47.6$, and $56.5^{\circ}$, corresponding to the (111), 
(200), (220) and (311) planes [33]. Evidences of phase segregation were not observed by $\mathrm{XRD}$ for the $\mathrm{Ce}-\mathrm{Zr}$ mixed oxide (Figure 11b), since $\mathrm{ZrO}_{2}$ characteristic peaks did not appear. However, a certain degree of inhomogeneous distribution of cerium and zirconium cannot be ruled out, as it will be next discussed in the context of $\mathrm{H}_{2}$-TPR characterization.

$\mathrm{Zr}$ incorporation into the fluorite structure of $\mathrm{CeO}_{2}$ caused the lattice deformation, and considering a same calcination temperature, the intensity of the $\mathrm{CeO}_{2}$ peaks is higher than that of the counterpart $\mathrm{Ce}_{0.76} \mathrm{Zr}_{0.24} \mathrm{O}_{2}$ mixed oxide. This is a consequence of the better arrangement of the atoms into the framework of pure $\mathrm{CeO}_{2}$ and to the decrease of the number of lattice defects. The effect of calcination temperature is clearly envisaged on Figure 11a. As calcination temperature increases the peaks of $\mathrm{CeO}_{2}$ become narrower. This is related to an increase in crystal size, which is consistent with BET and TEM characterization, and also with the negative effect of temperature in the catalytic activity of $\mathrm{CeO}_{2}$. The same effect of temperature is observed in the patterns included on Figure $11 \mathrm{~b}$ but in a lower extent, in agreement with the higher thermal stability of the Ce-Zr mixed oxide.

Raman characterization supports the conclusions of $\mathrm{XRD}$. All the $\mathrm{CeO}_{2}$ and $\mathrm{Ce}_{0.76} \mathrm{Zr}_{0.24} \mathrm{O}_{2}$ samples (Figures 12a and $12 \mathrm{~b}$ ) present the typical structure of $\mathrm{CeO}_{2}$ with the main band at $460 \mathrm{~cm}^{-1}$ attributed to the only allowed Raman mode $\left(\mathrm{F}_{2 \mathrm{~g}}\right)$ of a fluorite-type structure $[34,35]$. The Raman spectra of these fluorite-type oxide structures are dominated by oxygen lattice vibrations and are sensitive to the crystalline symmetry [36]. The presence of $\mathrm{Zr}^{4+}$ into the $\mathrm{CeO}_{2}$ lattice deforms the structure and the intensity of the fluoritecharacteristic peak decreases significantly, as deduced by comparison of Figure 12a with Figure $12 \mathrm{~b}$. It has been reported that this deformation favours oxygen mobility affecting the redox behaviour of the material [37]. The calcination temperature also affects the 
arrangement of atoms in the $\mathrm{CeO}_{2}$ lattice (Figure 12a), and the intensity of the Raman peak increases with calcination temperature as a consequence of the better arrangement of atoms. Raman characterization also provides evidences of the improved thermal stability of the Ce-Zr mixed oxide. As shown on Figure $12 \mathrm{~b}$, the intensities of the signals of $\mathrm{Ce}_{0.76} \mathrm{Zr}_{0.24} \mathrm{O}_{2}$ calcined between 500 and $900^{\circ} \mathrm{C}$ are about the same, and increase slightly when calcined at $1000^{\circ} \mathrm{C}$. The shift of the Raman signal towards lower energies that occurs in $\mathrm{Ce}_{0.76} \mathrm{Zr}_{0.24} \mathrm{O}_{2}$ calcined between 500 and $900^{\circ} \mathrm{C}$ with regard to $\mathrm{Ce}_{0.76} \mathrm{Zr}_{0.24} \mathrm{O}_{2}-1000$ is a sign of the improvement of oxygen mobility, which could be related to the presence of oxygen vacancies [38].

The redox properties of selected samples were investigated by $\mathrm{H}_{2}-\mathrm{TPR}$, and the $\mathrm{H}_{2}$ consumption profiles obtained have been plotted on Figure $13 . \mathrm{H}_{2}$ consumption must be attributed to the reduction of $\mathrm{Ce}^{4+}$ to $\mathrm{Ce}^{3+}$, since $\mathrm{Zr}^{4+}$ is a non-reducible cation. It is generally accepted [39] that two peaks characterise the reduction profile of pure $\mathrm{CeO}_{2}$. The first peak, centred at around $500{ }^{\circ} \mathrm{C}$ in the profile of $\mathrm{CeO}_{2}-500$, is attributed to the reduction of the uppermost layers of $\mathrm{Ce}^{4+}$ and the second peak, centred at $800^{\circ} \mathrm{C}$, is originated by the reduction of the bulk. The $\mathrm{H}_{2}$-consumption profile of $\mathrm{Ce}_{0.76} \mathrm{Zr}_{0.24} \mathrm{O}_{2}-500$ also shows this shape, but the peak intensity ratio (surface/bulk reduction) is higher for the mixed oxide. This suggests enhanced oxygen mobility within the $\mathrm{Ce}_{0.76} \mathrm{Zr}_{0.24} \mathrm{O}_{2}$ lattice in comparison with the bare $\mathrm{CeO}_{2}$. On the other hand, a certain degree of inhomogeneous distribution of cerium and zirconium can be also inferred. A broad $\mathrm{H}_{2}$-consumption band would be expected for a true $\mathrm{Ce}-\mathrm{Zr}$ solid solution, where the surface and bulk reduction would occur concurrently, but not a clear distinction between surface and bulk reduction. Wu et al. [40] also reported a bimodal $\mathrm{H}_{2}$-TPR profile for a $\mathrm{Ce}_{0.5} \mathrm{Zr}_{0.5} \mathrm{O}_{2}$ sample which was ascribed to a possible "shell/core structure" concordant with a heterogeneous surface elemental 
distribution. These authors reported a surface $\mathrm{Ce} / \mathrm{Zr}$ ratio of 1.3 , which is higher than the nominal ratio (1.0) for this sample. The results of XPS analysis performed with our $\mathrm{Ce}_{0.76} \mathrm{Zr}_{0.24} \mathrm{O}_{2}$ mixed oxide also showed a $\mathrm{Ce} / \mathrm{Zr}$ ratio of 5.0 , well above the value of 3.2 expected for this nominal composition. On this line, Nagai et al $[41,42]$ also assessed (by means of the XAFS technique) the existence of $\mathrm{Ce}$ - and $\mathrm{Zr}$-rich domains in a $\mathrm{Ce}_{0.5} \mathrm{Zr}_{0.5} \mathrm{O}_{2}$ solid solution prepared by co-precipitation and subsequent calcination at $500^{\circ} \mathrm{C} "$.

The profile of $\mathrm{CeO}_{2}-1000$ only contains the bulk reduction peak due to the very low BET surface area of this sample. The drastic effect of the calcination temperature on the surface redox properties of $\mathrm{CeO}_{2}$ is not so obvious in $\mathrm{Ce}_{0.76} \mathrm{Zr}_{0.24} \mathrm{O}_{2}$. The $\mathrm{H}_{2}$-consumption profile of $\mathrm{Ce}_{0.76} \mathrm{Zr}_{0.24} \mathrm{O}_{2}-1000$ shows a broad band instead of two well-defined peaks, and the onset temperature of this band is consistent to a surface reduction process. The generally accepted suggestion to explain this type of profile is that the surface and bulk reduction occurs concurrently [39], that is, there is not a clear distinction between surface and bulk peaks because oxygen located within the bulk comes to the surface when surface oxygen is consumed. This type of profiles is characteristic of materials with good oxygen mobility.

As a summary, the characterization of $\mathrm{CeO}_{2}$ and $\mathrm{Ce}_{0.76} \mathrm{Zr}_{0.24} \mathrm{O}_{2}$ allows concluding that both materials present fluorite structure, and that $\mathrm{Ce}-\mathrm{Zr}$ incorporates $\mathrm{Zr}^{4+}$ cations into the $\mathrm{CeO}_{2}$ framework. This incorporation of foreign cations enhances the thermal resistance of $\mathrm{CeO}_{2}$, diminishing thermal sintering. As a consequence of this improved thermal resistance, $\mathrm{Ce}_{0.76} \mathrm{Zr}_{0.24} \mathrm{O}_{2}$ calcined at high temperature presents higher BET surface area and improved redox properties than pure $\mathrm{CeO}_{2}$.

It is not easy to distinguish between the relative contribution of structural properties (BET area; particle size) and other properties like redox behaviour or lattice oxygen 
mobility, in the catalytic activity towards soot combustion of $\mathrm{CeO}_{2}$-based pure and mixed oxides. In order to get insight into this, the temperature for $50 \%$ soot conversion obtained from Temperature Programmed Reactions performed with the different $\mathrm{CeO}_{2}$ and $\mathrm{Ce}_{0.76} \mathrm{Zr}_{0.24} \mathrm{O}_{2}$ samples has been plotted as a function of their BET surface area on Figure 14. A relationship between both parameters is clearly observed, which allows concluding that the catalytic activity of pure $\mathrm{CeO}_{2}$ and that of the mixed oxide $\mathrm{Ce}_{0.76} \mathrm{Zr}_{0.24} \mathrm{O}_{2}$ depends on its surface area. A relationship between surface area and catalytic activity for soot oxidation in temperature programmed oxidations by $\mathrm{O}_{2}$, with soot and catalyst in tight contact, has been also reported for the catalyst $\mathrm{Ce}_{0.95} \mathrm{Fe}_{0.05} \mathrm{O}_{1.975}$ [19]. This catalyst was calcined at different temperatures in the range $500-750^{\circ} \mathrm{C}$, thus reaching surface areas in the range $92-10 \mathrm{~m}^{2} / \mathrm{g}$, respectively. A linear correlation between surface area and activity was obtained for surface areas below $40 \mathrm{~m}^{2} / \mathrm{g}$, while for larger area the variation in activity was not so relevant. In the present study, this threshold is not observed, probably because the soot and catalyst are in loose contact instead of tight. For experiments in loose contact, we also expect a threshold in surface area values above which the catalytic activity does not longer improves, but this limit seems to be above the maximum surface area reached in the current study $\left(67 \mathrm{~m}^{2} / \mathrm{g}\right)$.

In spite of the relationship between catalyst surface area and T50\% values obtained in temperature programmed reactions (Figure 14), the isothermal reactions performed at $500^{\circ} \mathrm{C}$ indicated that $\mathrm{Ce}_{0.76} \mathrm{Zr}_{0.24} \mathrm{O}_{2}-500$ presents better activity than $\mathrm{CeO}_{2}-500$ (and both samples present the same BET area). These differences could be explained by the improved redox properties, deduced from $\mathrm{H}_{2}$-TPR (Figure 13), and/or enhanced lattice oxygen mobility, deduced from Raman spectroscopy (Figure 12), of the mixed oxide. In conclusion, the structural properties of $\mathrm{CeO}_{2}$-based pure and mixed oxides play an 
important role on their catalytic activity for soot oxidation but other properties like redox behaviour and/or enhanced lattice oxygen mobility, also affect their performance.

\section{4.- Conclusions.}

As a summary of the current study, it can be concluded that the catalytic activity of $\mathrm{CeO}_{2}$ for Diesel-exhaust purification can be significantly improved by doping $\mathrm{CeO}_{2}$ with $\mathrm{Zr}^{4+}, \mathrm{Ce}_{0.76} \mathrm{Zr}_{0.24} \mathrm{O}_{2}$ being the best formulation among those prepared and tested. This $\mathrm{Ce}-\mathrm{Zr}$ mixed oxide presents a slightly higher activity than bare $\mathrm{CeO}_{2}$ for soot oxidation by $\mathrm{NO}_{\mathrm{x}} / \mathrm{O}_{2}$ when both catalysts are calcined at $500^{\circ} \mathrm{C}$ (soot oxidation rates at $500^{\circ} \mathrm{C}$ are 14.9 and 11.4 $\mu \mathrm{g}_{\text {soot }}$ (s, respectively), and both catalysts presents the same selectivity for $\mathrm{CO}_{2}$ formation as soot oxidation product. However, $\mathrm{Ce}_{0.76} \mathrm{Zr}_{0.24} \mathrm{O}_{2}$ shows enhanced thermal stability in comparison to pure $\mathrm{CeO}_{2}$ (as deduced form XRD, Raman, TEM, $\mathrm{N}_{2}$ adsorption and $\mathrm{H}_{2}$ TPR characterization), maintaining part of its activity for soot oxidation and selectivity towards $\mathrm{CO}_{2}$ formation after calcination at temperatures as high as $1000^{\circ} \mathrm{C}$.

In addition, $\mathrm{Ce}_{0.76} \mathrm{Zr}_{0.24} \mathrm{O}_{2}$ catalyses more efficiently than $\mathrm{CeO}_{2}$ the reduction of $\mathrm{NO}_{\mathrm{x}}$ by soot around $500^{\circ} \mathrm{C}$, therefore contributing to the decrease of the $\mathrm{NO}_{\mathrm{x}}$ emission level.

The catalytic activity of $\mathrm{CeO}_{2}$ and $\mathrm{Ce}_{0.76} \mathrm{Zr}_{0.24} \mathrm{O}_{2}$ for soot oxidation by $\mathrm{NO}_{\mathrm{x}} / \mathrm{O}_{2}$ depends on their textural properties (BET area; crystallite size), but other properties of the oxides, like redox behaviour and/or enhanced lattice oxygen mobility, also play a significant role. 


\section{Acknowledgements}

The authors thank the financial support of the project CTQ2005-01358 of the

Spanish Ministry of Education and Science and ABL the contract funded by the Ramon $y$ Cajal Program and the Generalidat Valenciana. 


\section{Literature}

[1] M. V. Twigg, Appl. Catal. B 70 (2007) 2.

[2] J. Kašpar, P. Fornasiero, M. Graziani, Catal. Today 50 (1999) 285.

[3] A. Trovarelli. "Catalysis by Ceria and Related Materials". Catalytic Science Series, Vol. 2, Imperial College Press, p. 281 (2002).

[4] H.S. Gandhi, G.W. Graham, R.W. McCabe, J. Catal. 216 (2003) 433.

[5] P. Fornasiero, G. Balducci, J. Kašpar, S. Meriani, R. di Monte, M. Graziani. Catal. Today 29 (1996) 47.

[6] C. E. Hori, H. Permanaa, K.Y. Simon Ng, A. Brenner, K. More, K. M. Rahmoellerd, D. Belton, Appl.Catal. B 16 (1998) 105.

[7] M. Daturi, E. Finocchio, C. Binet, J.C. Lavalley, F. Fally, V. Perrichon, H. Vidal, N. Hickey, J. Kašpar. J. Phys. Chem. B 104 (2000) 9186.

[8] N. Hickey, P. Fornasiero, J. Kašpar, J. M. Gatica, S. Bernal. J. Catal. 200 (2001) 181.

[9] G. Balducci, J. Kašpar, P. Fornasiero, M. Graziani, M. Saiful Islam, J. Phys. Chem. B 102 (1998) 557.

[10] B.M. Reddy, P. Lakshmanan, P. Bharali, P. Saikia, G. Thrimurthulu, M. Muhler, W. Gru1nert, J. Phys. Chem. C 111 (2007) 10478.

[11] S. Eriksson, S. Rojas, M. Boutonnet, J.L.G. Fierro, Appl. Catal. A 326 (2007) 8.

[12] D. Terribile, A. Trovarelli, C. de Leitenburg, A. Primavera, G. Dolcetti, Catal. Today 47 (1999) 133.

[13] J. I. Gutiérrez-Ortiz, B. de Rivas, R. López-Fonseca, J. R. González-Velasco, Appl. Catal. B 65 (2006) 191.

[14] F. Fally, V. Perrichon, H. Vidal, J. Kašpar, G. Blanco, J.M. Pintado, S. Bernal, G. Colon, M. Daturi, J.C. Lavalley, Catal. Today 59 (2000) 373.

[15] I. Atribak, A. Bueno-López, A. García-García, Catal. Commun. 9 (2008) 250.

[16] A. Bueno-López, K. Krishna, M. Makkee, J. A. Moulijn, Catal. Letters 99 (2005) 203.

[17] B. A. A. L. van Setten, M. Makkee, J. A. Moulijn, Catal. Rev. 43 (2001) 489.

[18] J. P.A. Neeft, M. Makkee, J. A. Moulijn, Fuel. Proc. Technol. 47 (1996) 1.

[19] E. Aneggi, C. de Leitenburg, G. Dolcetti, A. Trovarelli, Catal. Today 114 (2006) 40. 
[20] A. Bueno-López, K. Krishna, M. Makkee, J.A. Moulijn, J. Catal. 230 (2005) 237.

[21] K. Krishna, A. Bueno-López, M. Makkee, J.A. Moulijn, Appl. Catal. B 75 (2007) 189.

[22] I. Atribak, I. Such-Basáñez, A. Bueno-López, A. García García, J. Catal. 250 (2007) 75.

[23] A. Setiabudi, J.Chen, G. Mul, M. Makkee, J. A. Moulijn, Appl. Catal. B 51 (2004) 9.

[24] K. Krishna, A. Bueno-López, M. Makkee, J.A. Moulijn, Appl. Catal. B 75 (2007) 201.

[25] K. Krishna, A. Bueno-López, M. Makkee, J.A. Moulijn, Appl. Catal. B 75 (2007) 210.

[26] M.L. Pisarello, V. Milt, M.A. Peralta, C.A. Querini, E.E. Miró, Catal. Today 75 (2002) 465 .

[27] B.A.A.L. van Setten, J.M. Schouten, M. Makkee, J.A. Moulijn, Appl. Catal. B 28 (2000) 253.

[28] M. Adamowska, S. Muller, P. Da Costa, A. Krzton, P. Burg, Appl. Catal. B 74 (2007) 278.

[29] M. Pijolat, M. Prin, M. Soustelle, O. Touret, P. Nortier, J. Chem. Soc. Faraday Trans. 91 (1995) 3941.

[30] A. Setiabudi, M. Makkee, J. A. Moulijn. Appl. Catal. B 50 (2004) 185.

[31] A. Bueno-López, A. García-García, J.A. Caballero-Suárez, Environ. Sci. Technol. 36 (2002) 5447.

[32] A. Bueno-López, A. García-García, A. Linares-Solano, Fuel Proc. Technol. 77-78 (2002) 301 .

[33] D. Terribile, A. Trovarelli, J. Llorca, C. de Leitenburg, G. Dolcetti, Catal. Today 43 (1998) 79.

[34] A. Nineshige, T. Taji, Y. Muroi, M. Kobune, S. Fujii, N. Nishi, M. Inaba, Z. Ogumi, Solid State Ionics 135 (2000) 481.

[35] L.N. Ikryannikova, A.A. Aksenov, G.L. Markayan, G.P. Muravieva, B.G. Kostyuk, A.N. Kharlanov, E.V. Linina, Appl. Catal. A 210 (2001) 225.

[36] M. Fernandez-García, A. Martínez-Arias, A. Iglesias-Juez, C. Belver, A.B. Hungría, J.C. Conesa, J. Soria, J. Catal. 194 (2000) 385.

[37] P. Fornasiero, J. Kašpar, M. Grazini, J. Catal. 167 (1997) 576.

[38] S. Rossignol, C. Descorme, C. Kappenstein, D. Duprez, J. Mater. Chem. 11 (2001) 2587. 
[39] G.L. Markaryan, L.N. Ikryannikova, G.P. Muravieva, A.O. Turakulova, B.G. Kostyuk, E.V. Lunina, V.V. Lunin, E. Zhilinskaya, A. Aboukais, Colloids Surfaces A 151 (1999) 435.

[40] W. Xiadong, L. Qing, W. Xiaodi, W. Duan, J. Rare Earths 25 (2007) 416.

[41] Y. Nagai, T. Yamamoto, T. Tanaka, S. Yoshida, T. Nonaka, T. Okamoto, A. Suda, M. Sugiura, J. Synchrotron Rad. 8 (2001) 616.

[42] Y. Nagai, T. Yamamoto, T. Tanaka, S. Yoshida, T. Nonaka, T. Okamoto, A. Suda, M. Sugiura, Catal. Today 74 (2002) 225. 


\section{FIGURE CAPTIONS}

Figure 1. Effect of the Ce:Zr ratio on soot combustion.

Figure 2. Effect of the Ce:Zr ratio on $\mathrm{CO}$ emission.

Figure 3. Effect of the calcination temperature of catalyst on soot combustion.

Figure 4. Effect of the calcination temperature of catalyst on $\mathrm{CO}$ emission.

Figure 5. Effect of the Ce: $\mathrm{Zr}$ ratio on: (a) $\mathrm{NO}_{\mathrm{x}}$ elimination and (b) $\mathrm{O}_{2}$ elimination (catalysts calcined at $500^{\circ} \mathrm{C}$ ).

Figure 6. Blank experiments (without soot): (a) $\mathrm{NO}_{\mathrm{x}}$ elimination and (b) $\mathrm{NO}_{2}$ formation.

Figure 7. Effect of the calcination temperature of catalyst on $\mathrm{NO}_{\mathrm{x}}$ elimination: (a) $\mathrm{CeO}_{2^{-}}$ series and (b) $\mathrm{Ce}_{0.76} \mathrm{Zr}_{0.24} \mathrm{O}_{2}$-series.

Figure 8. Isothermal reactions at $500^{\circ} \mathrm{C}$ : (a) soot oxidation rate and (b) $\mathrm{NO}_{\mathrm{x}}$ elimination. (The units of soot oxidation rate are mg of soot converted per second and gram of soot remaining in the reactor)

Figure 9. BET surface areas in terms of calcination temperature of catalysts.

Figure 10. TEM images: a) $\mathrm{CeO}_{2}-500$, b) $\mathrm{CeO}_{2}-1000$, c) $\mathrm{Ce}_{0.76} \mathrm{Zr}_{0.24} \mathrm{O}_{2}-500$, d) $\mathrm{Ce}_{0.76} \mathrm{Zr}_{0.24} \mathrm{O}_{2}-1000$.

Figure 11. $\mathrm{XRD}$ characterisation of catalysts: (a) $\mathrm{CeO}_{2}$-series and (b) $\mathrm{Ce}_{0.76} \mathrm{Zr}_{0.24} \mathrm{O}_{2}$-series.

Figure 12. Raman characterisation of catalysts: (a) $\mathrm{CeO}_{2}$-series and (b) $\mathrm{Ce}_{0.76} \mathrm{Zr}_{0.24} \mathrm{O}_{2^{-}}$ series.

Figure 13. $\mathrm{H}_{2}$ consumption profiles during $\mathrm{H}_{2}$-TPR for selected catalysts.

Figura 14. T50\% parameter versus $\mathrm{BET}$ surface area of catalysts $\left(\mathrm{CeO}_{2}\right.$-series and $\mathrm{Ce}_{0.76} \mathrm{Zr}_{0.24} \mathrm{O}_{2}$-series). 
Table 1. Data estimated from isothermal reactions at $500^{\circ} \mathrm{C}$.

\begin{tabular}{|c|c|c|c|}
\hline Catalyst & $\begin{array}{c}\mathrm{CO} / \mathrm{CO}_{\mathrm{x}} \\
(\%)\end{array}$ & $\begin{array}{c}\text { Time for } 75 \% \text { soot } \\
\text { conversion (min) }\end{array}$ & $\begin{array}{c}\text { Average soot oxidation } \\
\text { rate }\left(\mu \mathrm{g}_{\text {soot }} / \mathrm{s}\right)\end{array}$ \\
\hline $\mathrm{CeO}_{2}-500$ & 2.1 & 24 & 11.4 \\
\hline $\mathrm{CeO}_{2}-1000$ & 11.3 & 172 & 1.2 \\
\hline $\mathrm{Ce}_{0.76} \mathrm{Zr}_{0.24} \mathrm{O}_{2}-500$ & 3.5 & 19 & 14.9 \\
\hline $\mathrm{Ce}_{0.76} \mathrm{Zr}_{0.24} \mathrm{O}_{2}-1000$ & 36.8 & 62 & 4.1 \\
\hline
\end{tabular}

Table 2. Crystal sizes determined from XRD.

\begin{tabular}{lcc}
\hline & $\begin{array}{c}\text { Crystal size (nm) } \\
\text { with Williamson- } \\
\text { Hall's equation }\end{array}$ & $\begin{array}{c}\text { Crystal size (nm) } \\
\text { with Scherrer's } \\
\text { equation }\end{array}$ \\
\hline $\mathrm{CeO}_{2}-500$ & 22 & 14 \\
$\mathrm{CeO}_{2}-600$ & 22 & 19 \\
$\mathrm{CeO}_{2}-700$ & 46 & 32 \\
$\mathrm{CeO}_{2}-800$ & 63 & 38 \\
$\mathrm{CeO}_{2}-900$ & 116 & 58 \\
$\mathrm{CeO}_{2}-1000$ & 107 & 55 \\
\hline $\mathrm{Ce}_{0.76} \mathrm{Zr}_{0.24} \mathrm{O}_{2}-500$ & 10 & 11 \\
$\mathrm{Ce}_{0.76} \mathrm{Zr}_{0.24} \mathrm{O}_{2}-600$ & 21 & 13 \\
$\mathrm{Ce}_{0.76} \mathrm{Zr}_{0.24} \mathrm{O}_{2}-700$ & 20 & 9 \\
$\mathrm{Ce}_{0.76} \mathrm{Zr}_{0.24} \mathrm{O}_{2}-800$ & 17 & 12 \\
$\mathrm{Ce}_{0.76} \mathrm{Zr}_{0.24} \mathrm{O}_{2}-900$ & 19 & 13 \\
$\mathrm{Ce}_{0.76} \mathrm{Zr}_{0.24} \mathrm{O}_{2}-1000$ & 65 & 22 \\
\hline
\end{tabular}




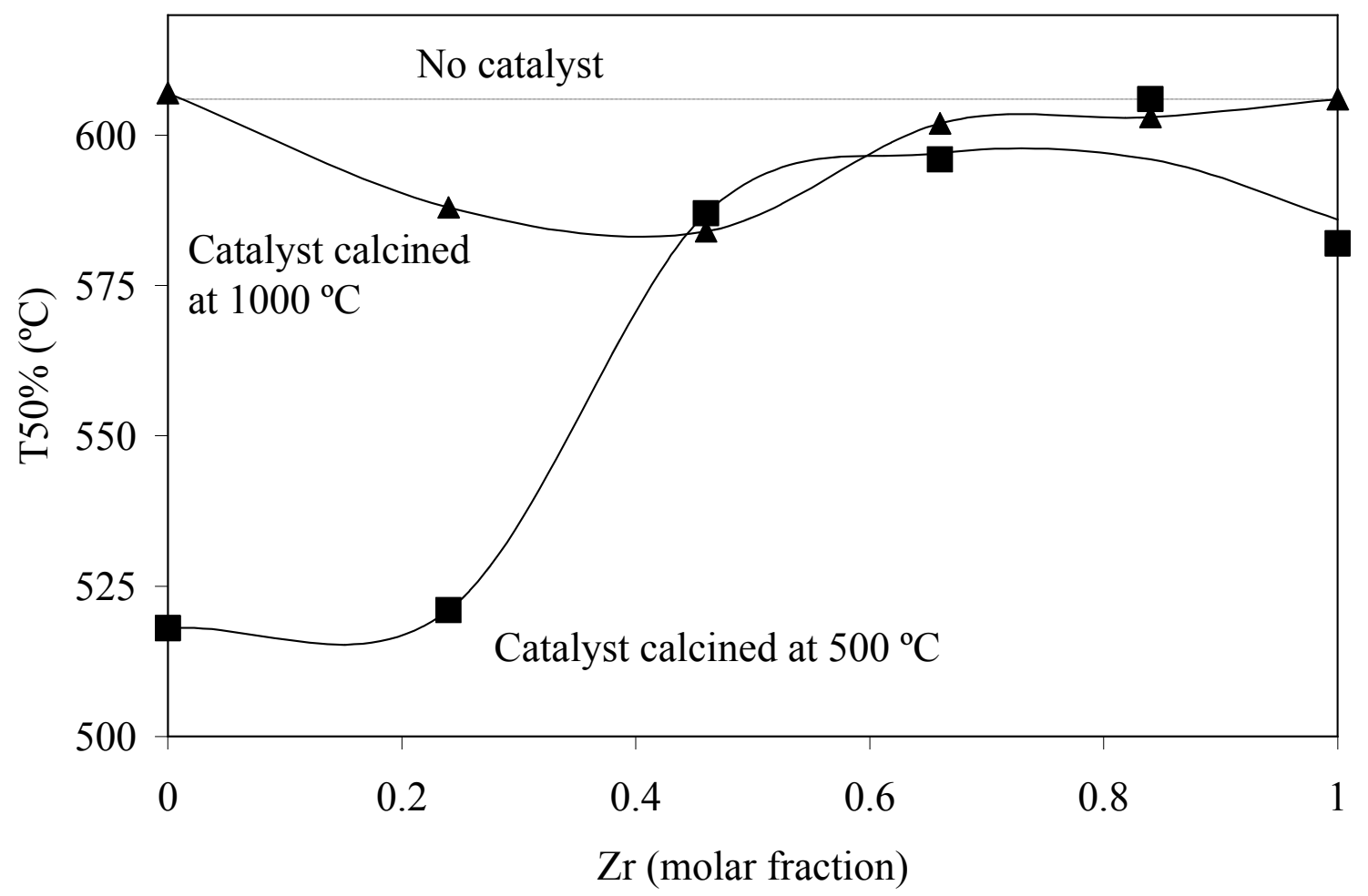

Figure 1 


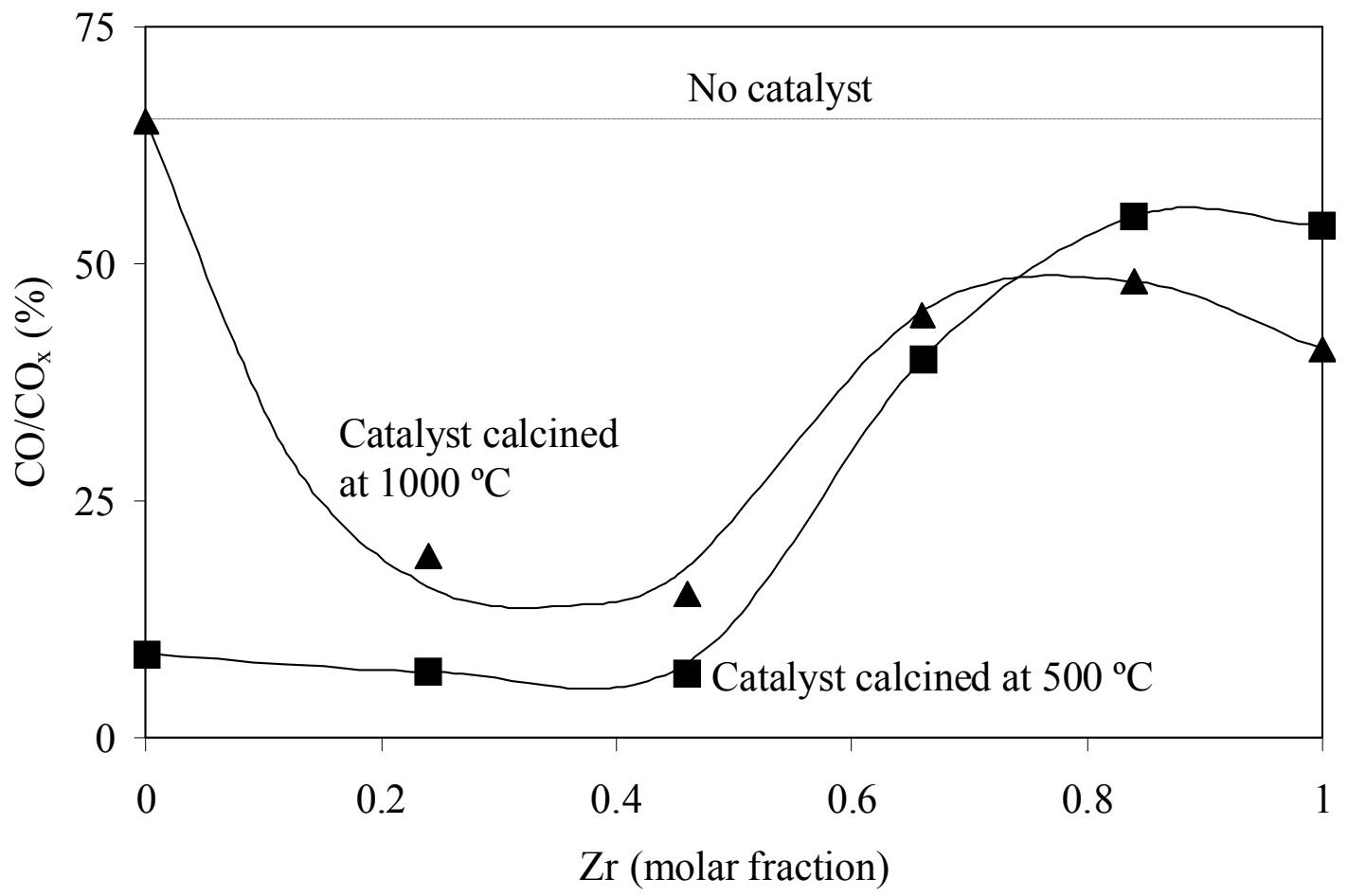

Figure 2 


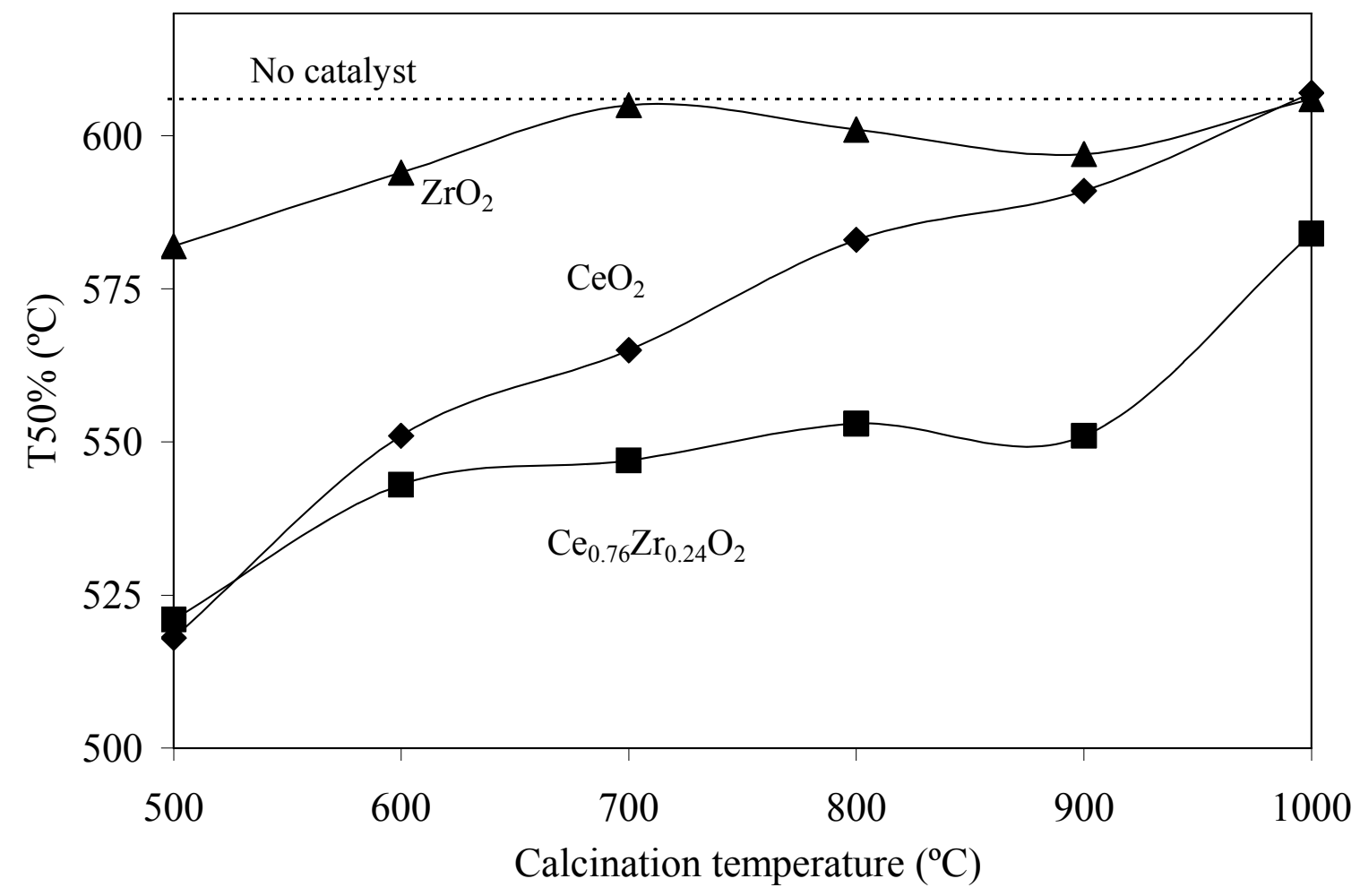

Figure 3 


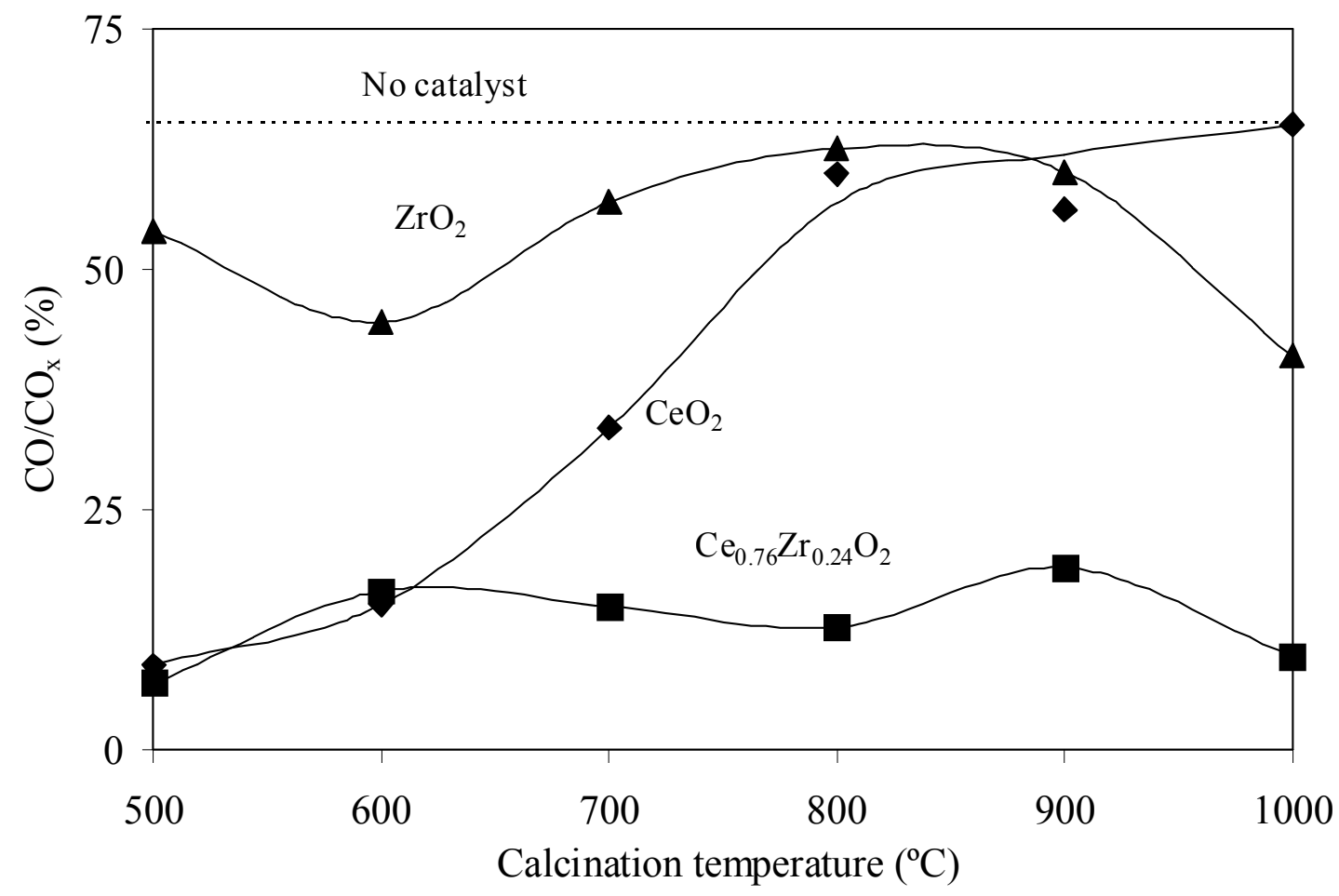

Figure 4 

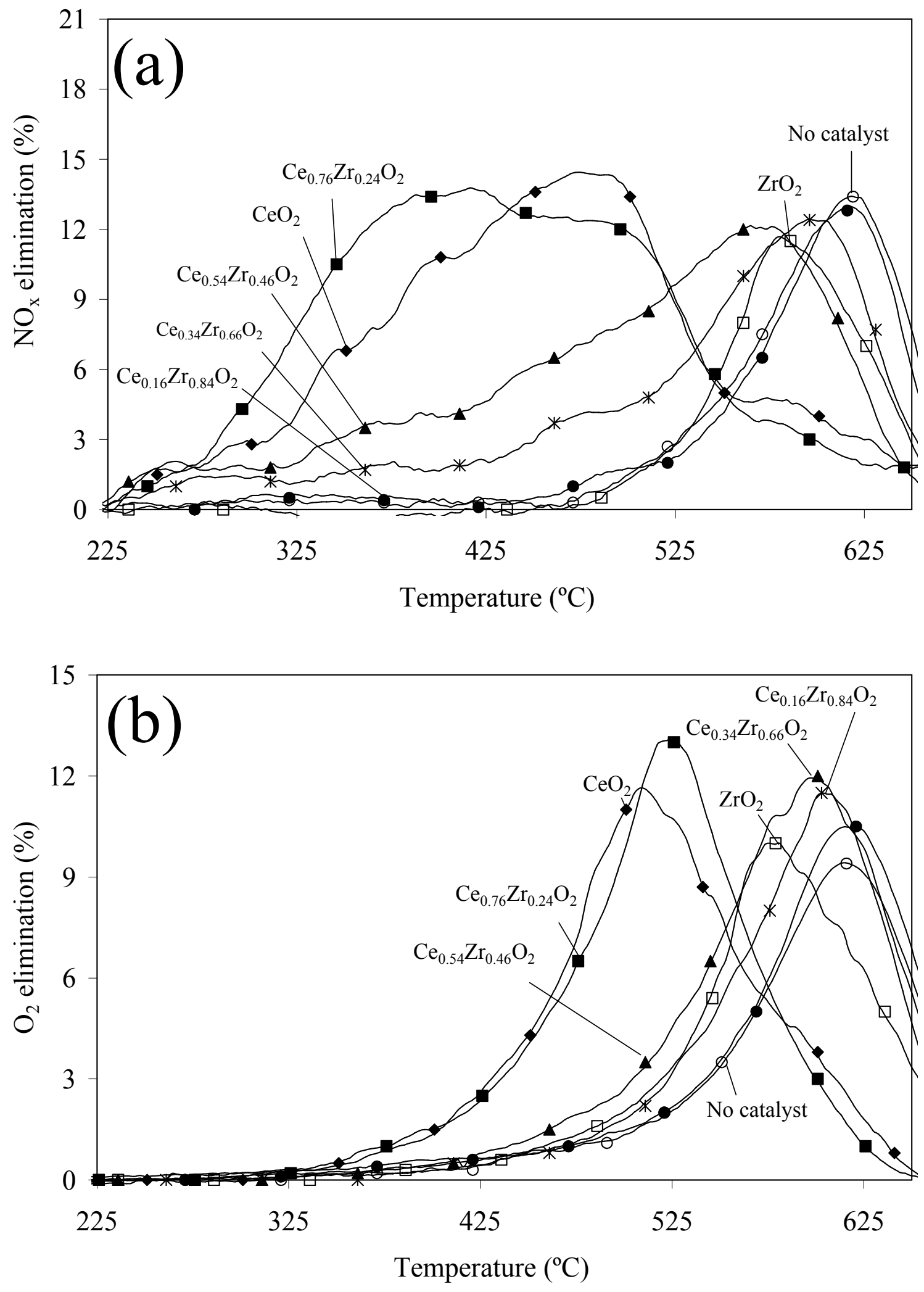

Figure 5 

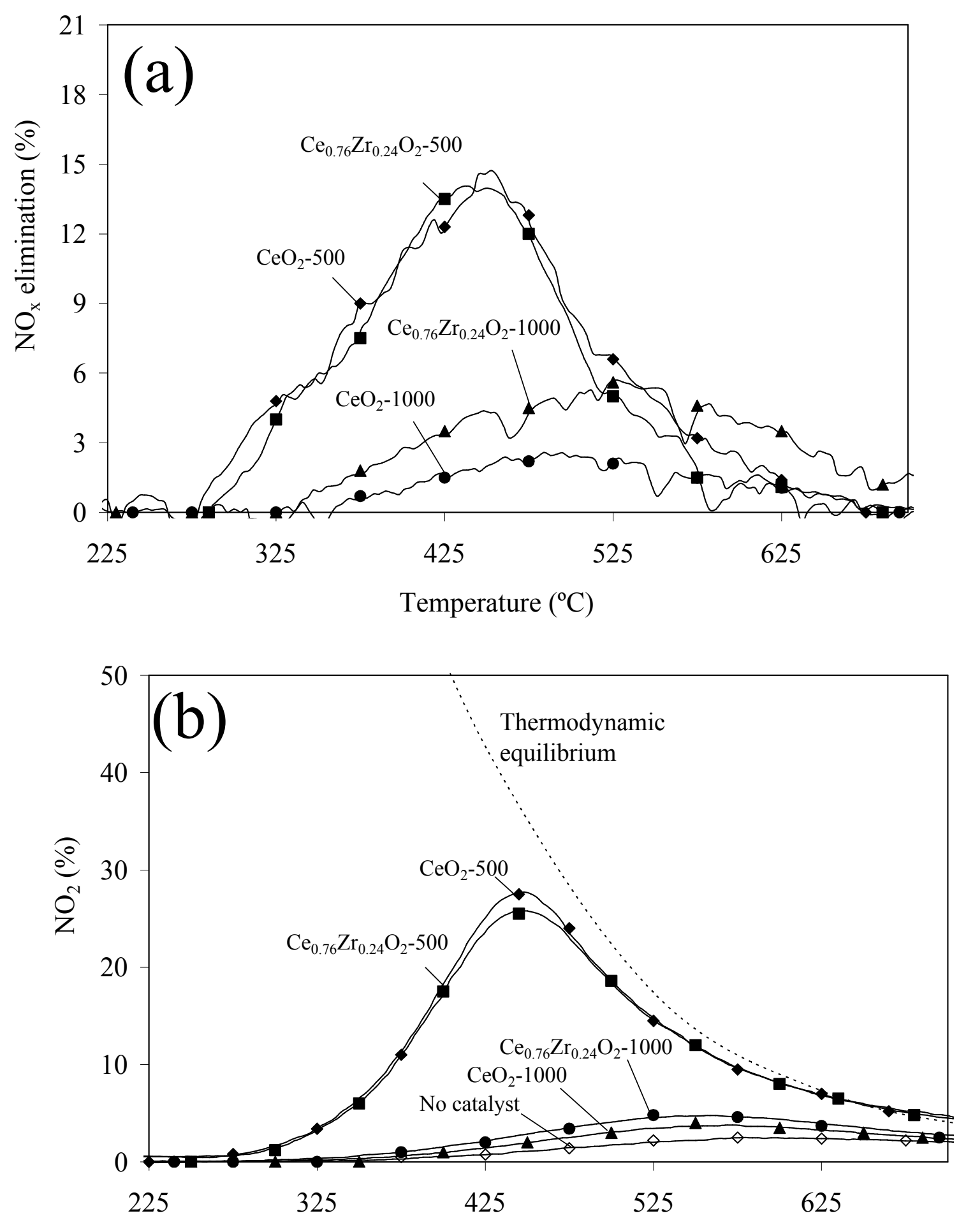

Temperature $\left({ }^{\circ} \mathrm{C}\right)$

Figure 6 

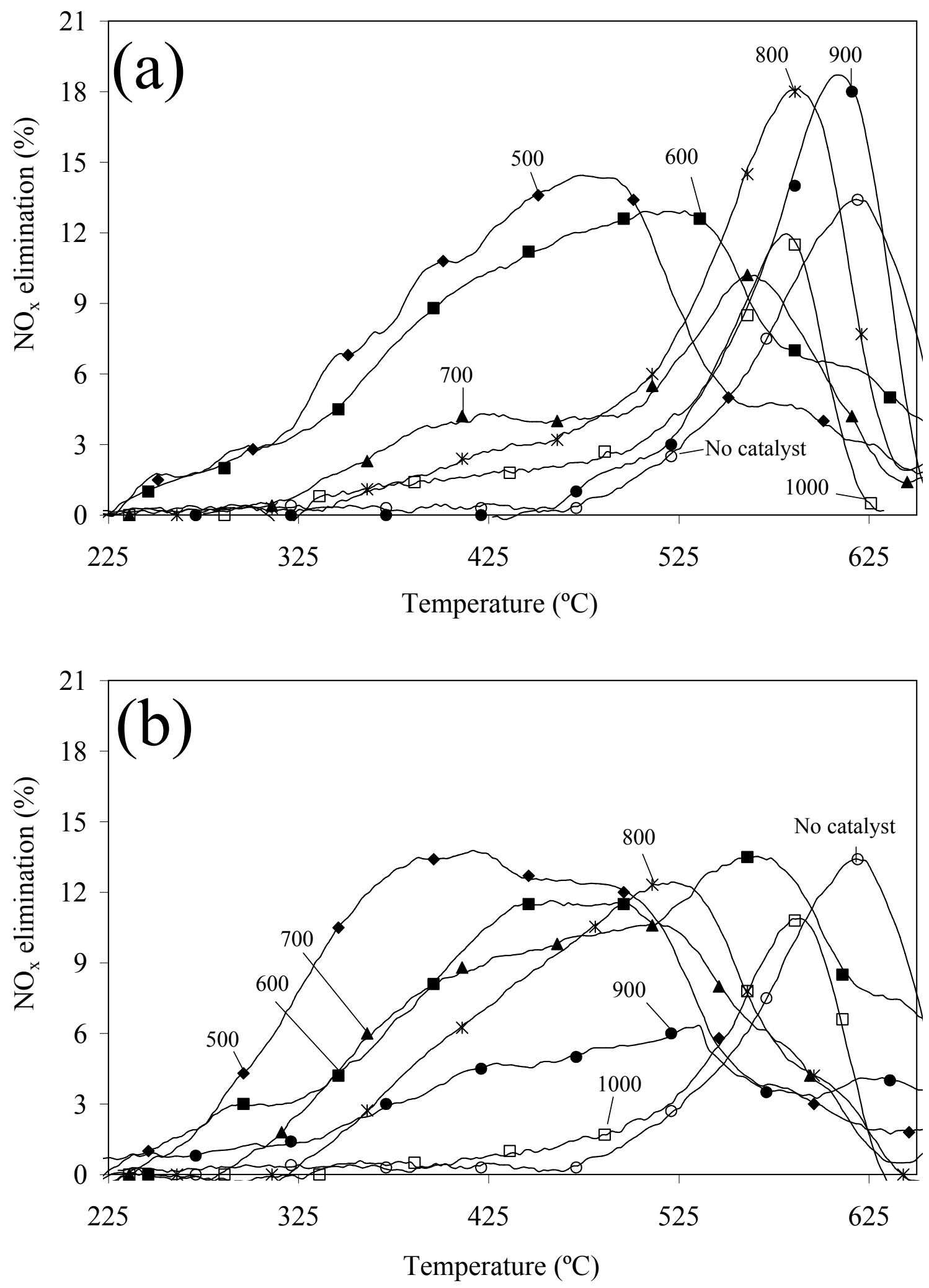

Figure 7 

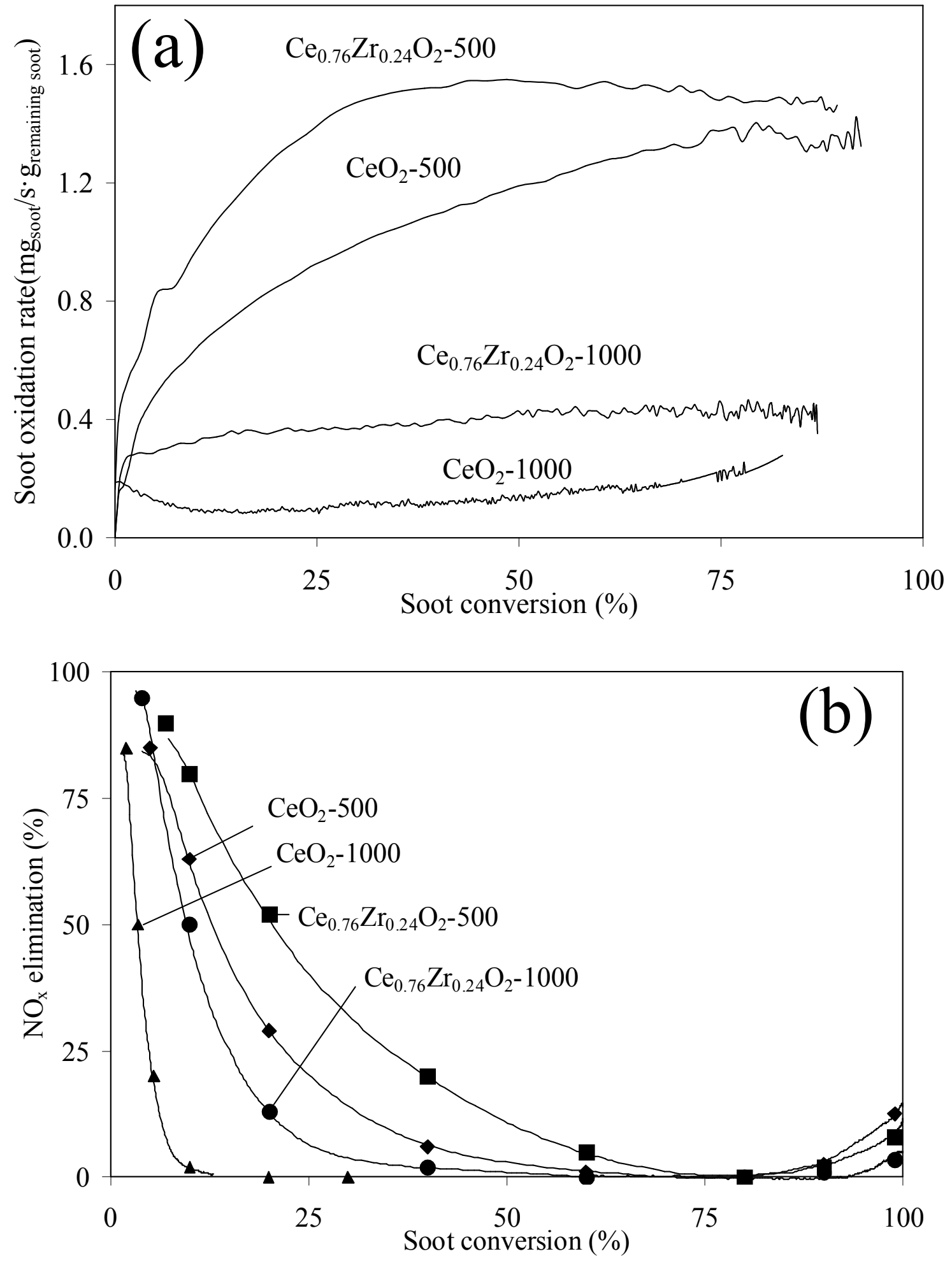

Figure 8 


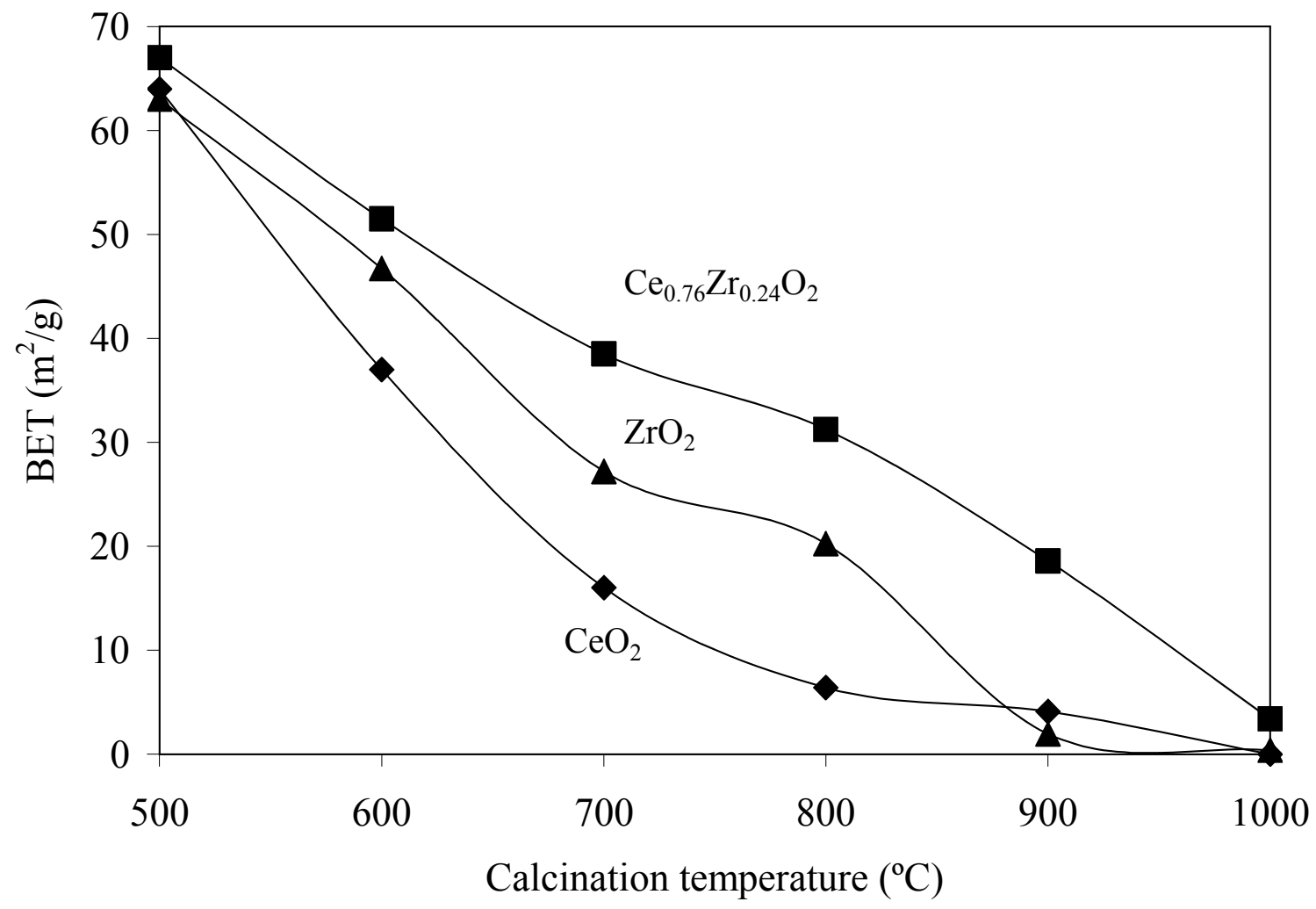

Figure 9 

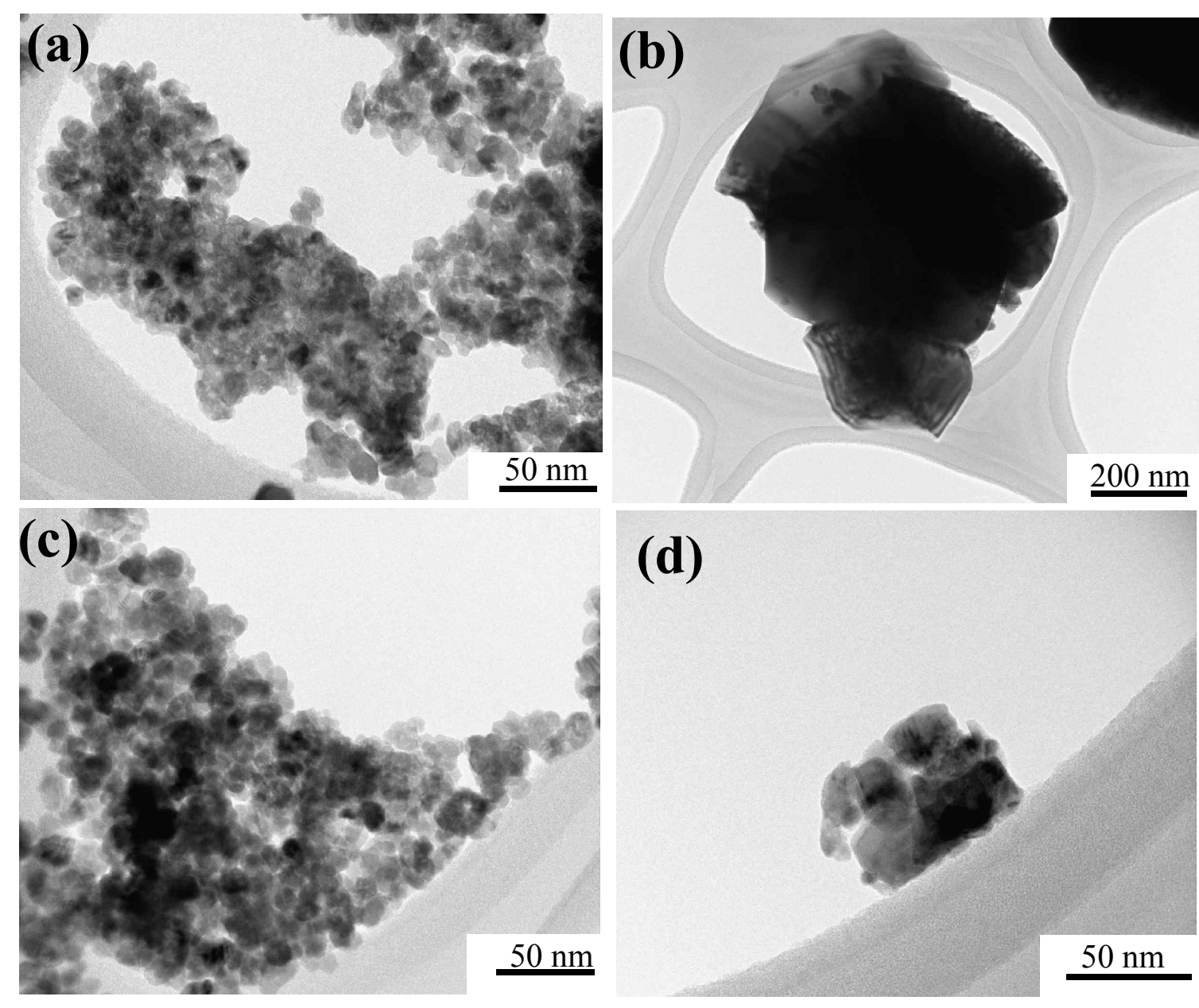

(d)

Figure 10 

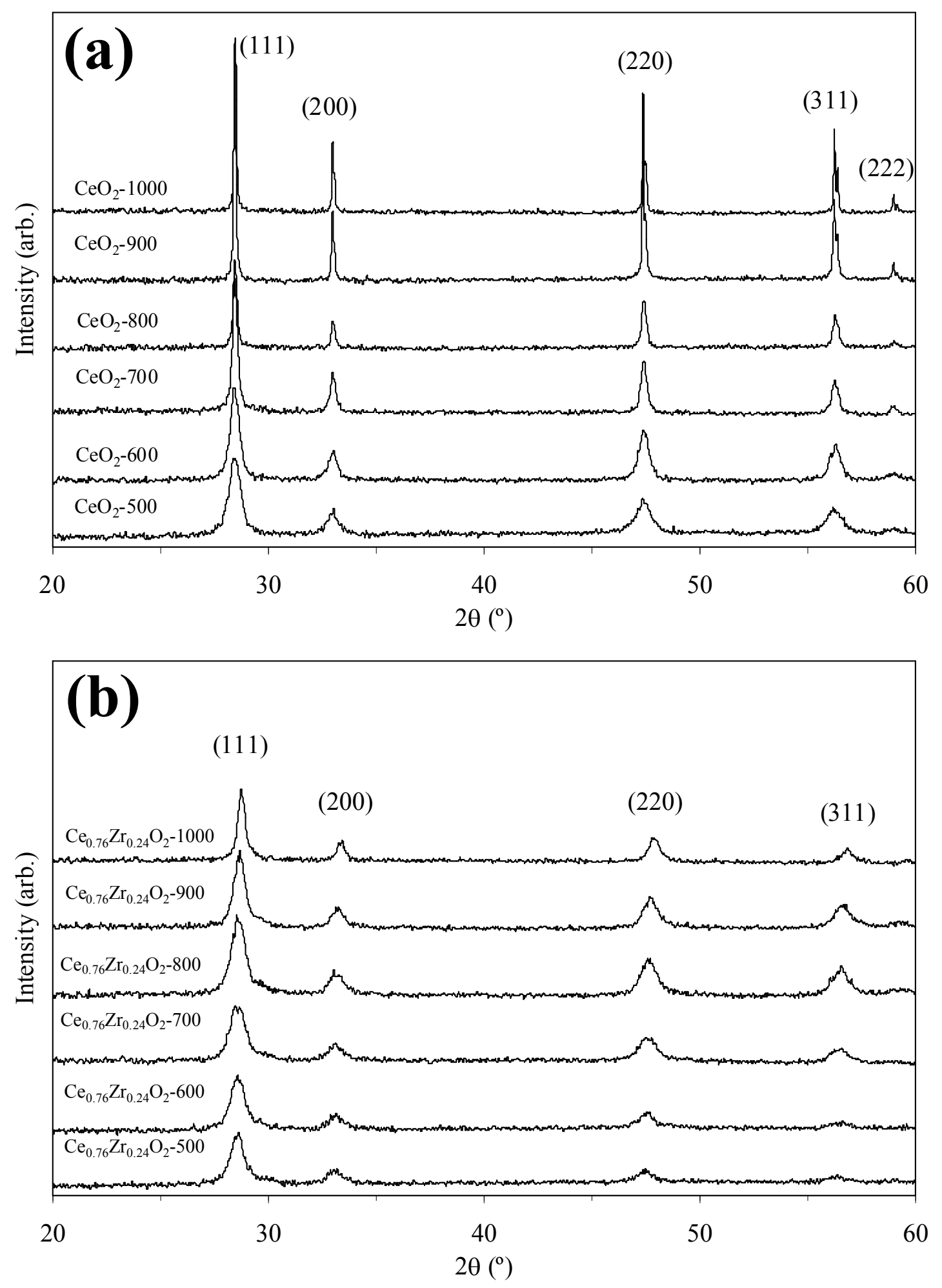

Figure 11 

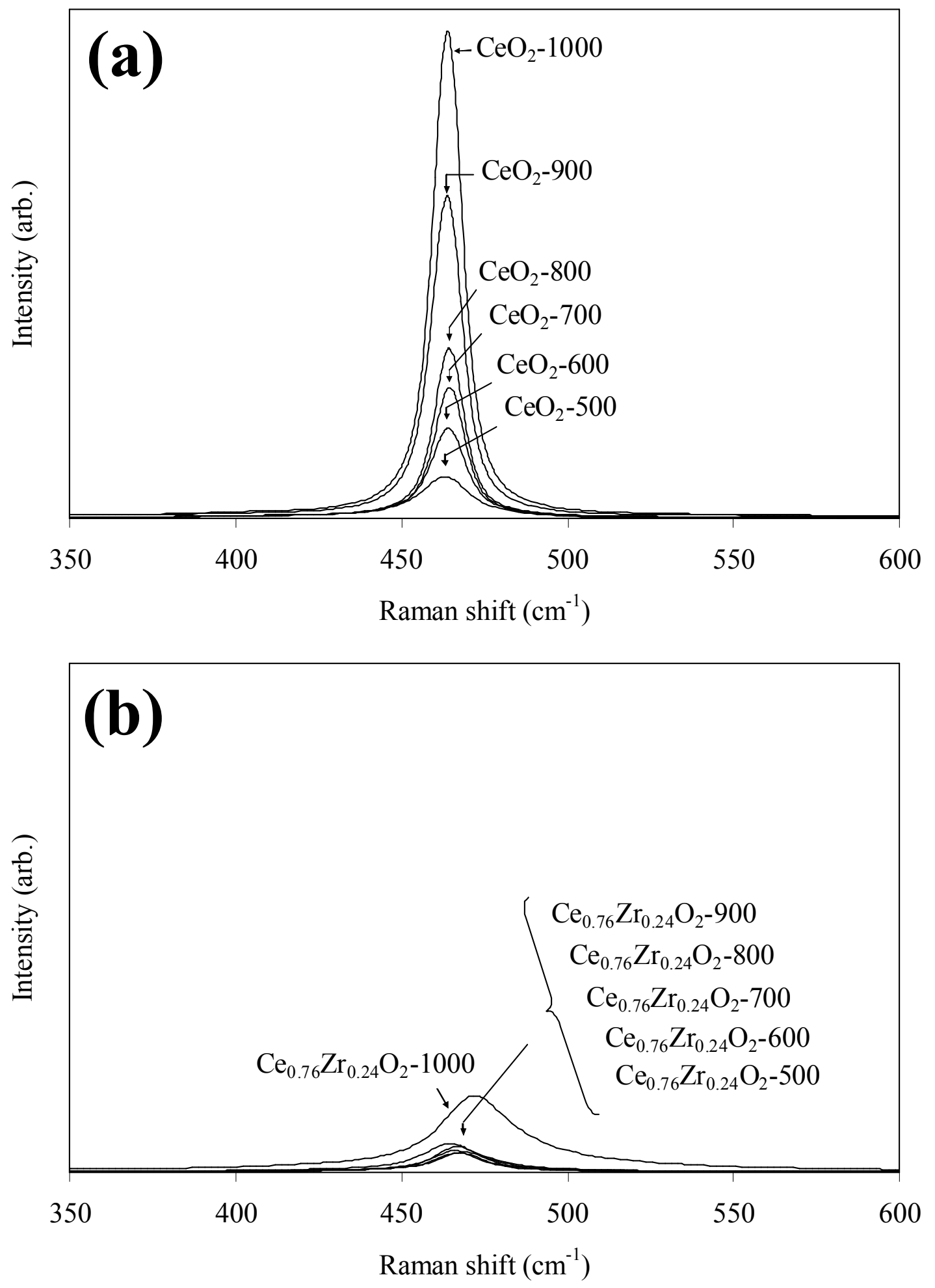

Figure 12 


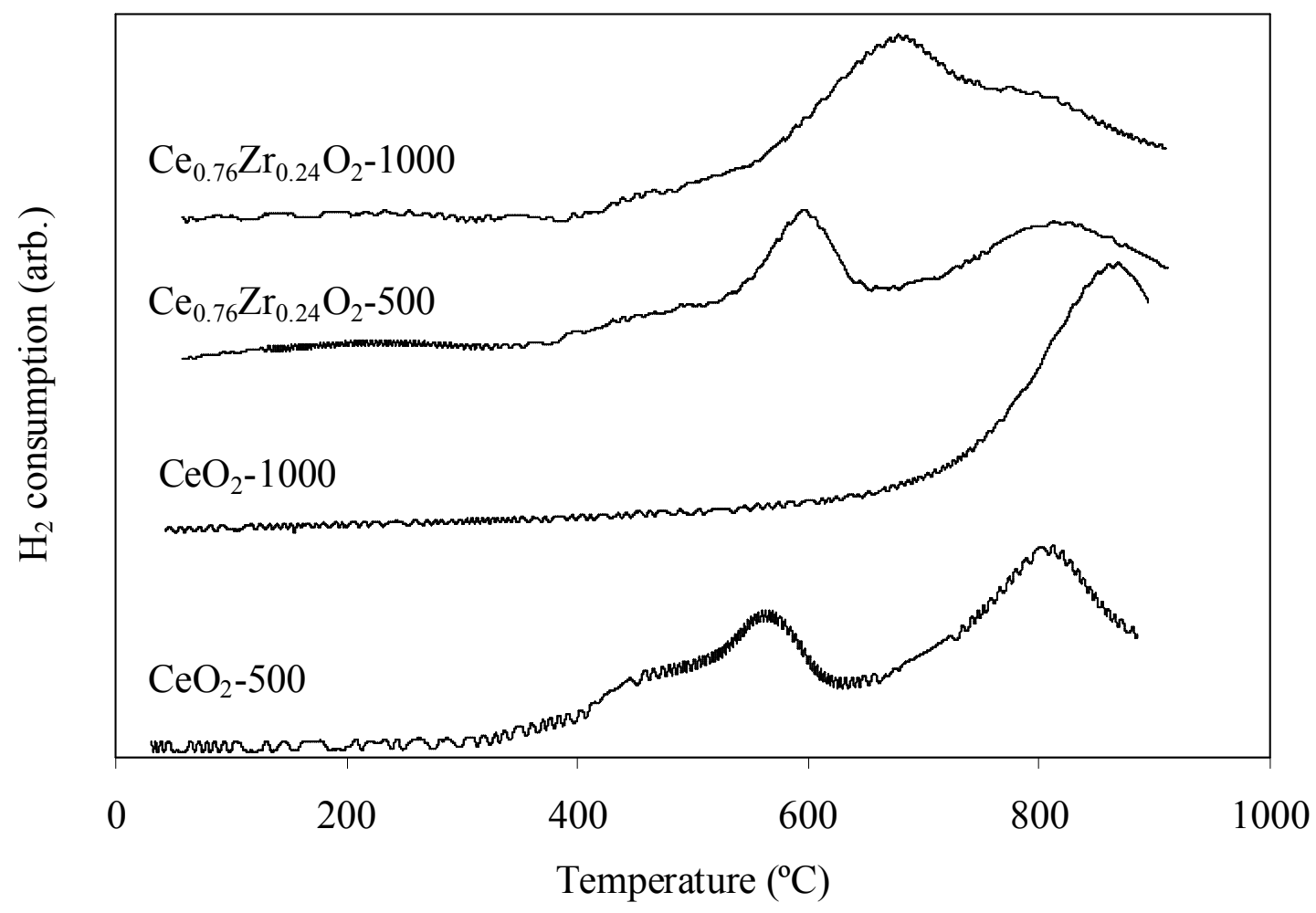

Figure 13 


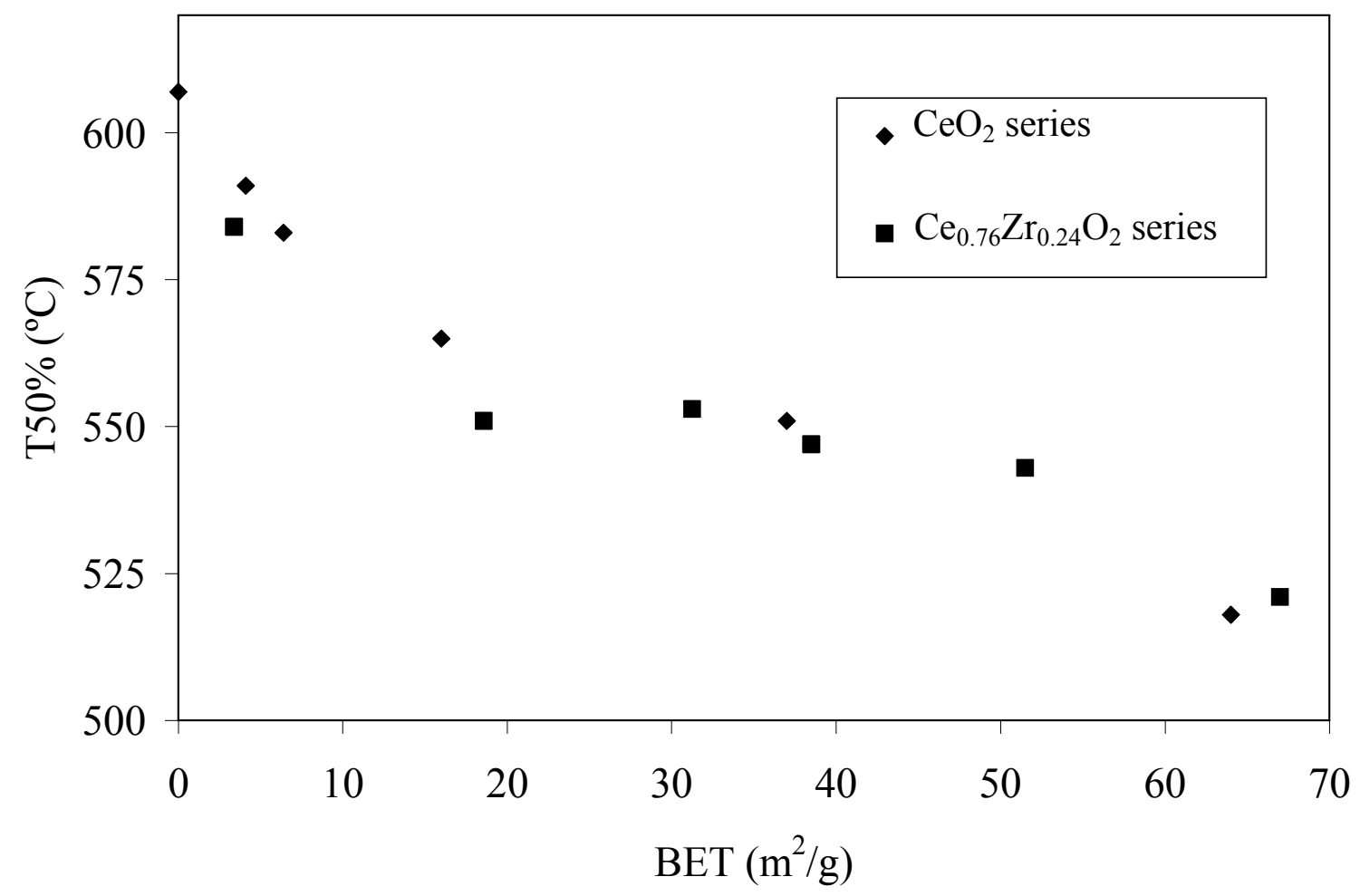

Figure 14 